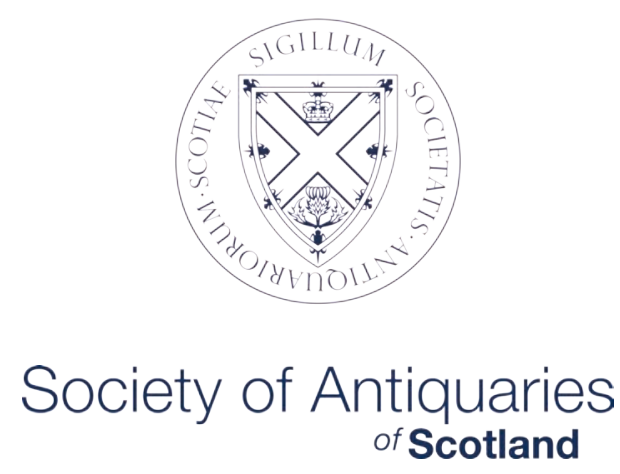

\title{
SCOTTISH ARCHAEOLOGICAL INTERNET REPORTS
}

\author{
e-ISSN: 2056-7421
}

\section{A Roman Road Runs Through It: Excavations at Newbridge, Edinburgh}

\section{How to cite:}

Engl, Rob \& Dunbar, Lindsay 2016 'A Roman Road Runs Through It: Excavations at Newbridge, Edinburgh'. Scottish Archaeological Internet Reports 59.

DOI link: https://doi.org/10.9750/issn.2056-7421.2016.59

Click http://journals.socantscot.org/index.php/sair to visit the journal homepage.

OPEN

\section{Please note:}

This document is the publisher's PDF of an article published in the Scottish Archaeological Internet Reports journal. This version has been peerreviewed and contains all final editorial corrections and journal pagination.

Copyright (C) 2016 rests with the Society and the individual authors. Except where otherwise noted, this work is licensed under Creative Commons Attribution-NonCommercial-No Derivatives licence. http://creativecommons.org/licenses/by-nc-nd/4.0/

The permission to reproduce the Society's copyright-protected material does not extend to any material which is identified as being the copyright of a third party. Authorisation to reproduce such material must be obtained from the copyright holders concerned.

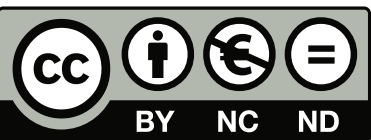




\title{
A Roman Road Runs Through It: Excavations at Newbridge, Edinburgh
}

\author{
Rob Engl \& Lindsay Dunbar \\ with contributions by \\ Nick Johnstone, George Haggarty \& Jackaline Robertson \\ Illustrations by Stefan Sagrott
}

\section{Address}

AOC Archaeology Group, Unit 7a, Edgefield Industrial Estate, Loanhead EH20 9SY

\section{Author contact}

Rob.engl@aocarchaeology.com

\section{Funding}

Rooster II LLP

e-ISSN: 2056-7421

https://doi.org/10.9750/issn.2056-7421.2016.59

Published by the Society of Antiquaries of Scotland with the

Archaeology Data Service archaeologydataservice.ac.uk.

Society of Antiquaries of Scotland

National Museums Scotland

Chambers Street

Edinburgh EH1 1JF

United Kingdom

Managing Editor: Erin Osborne-Martin

Copy-editor: Susan Milligan

Production: Raspberry Creative Type, Edinburgh

Copyright (C) 2016 rests with the Society and the individual authors. Except where otherwise noted, this work is licensed under Creative Commons Attribution-NonCommercial-NoDerivatives licence. http://creativecommons.org/licenses/by-nc-nd/4.0/

Requests for permission to reproduce material from a SAIR report should be sent to the Director of the Society of Antiquaries of Scotland, as well as to the author, illustrator, photographer or other copyright holder.

www.socantscot.org

Registered Scottish charity no SC010440 
List of illustrations $\quad$ iv

List of tables $\quad$ iv

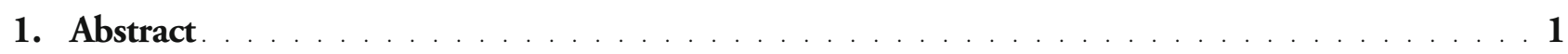

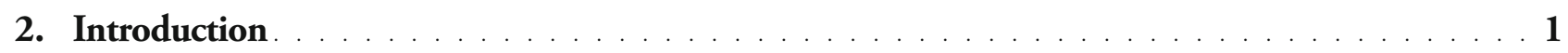

3. Prehistoric and Roman Activity . . . . . . . . . . . . . . . 4

3.1 Summary of the environmental evidence $\quad 4$

3.2 Summary of the artefactual evidence $\quad 4$

$\begin{array}{ll}3.3 \text { Mesolithic activity } & 4\end{array}$

3.4 Middle Bronze Age activity $\quad 6$

3.5 Pre-Roman Iron Age activity 6

$\begin{array}{ll}3.6 \text { Roman activity } & 11\end{array}$

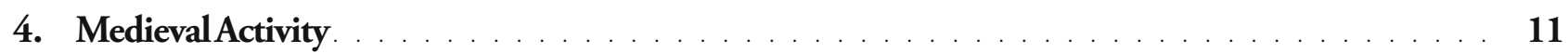

$\begin{array}{ll}4.1 \text { Introduction } & 11\end{array}$

$\begin{array}{ll}\text { 4.2 Dating evidence } & 13\end{array}$

4.3 Summary of the artefactual evidence $\quad 13$

$\begin{array}{ll}4.4 \text { Summary of the environmental evidence } & 13\end{array}$

4.5 Field systems and enclosures $\quad 13$

$\begin{array}{ll}4.6 \text { Pits } & 15\end{array}$

$\begin{array}{ll}4.7 \text { Structures } & 15\end{array}$

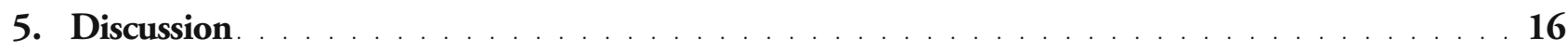

$\begin{array}{ll}5.1 \text { Prehistoric activity } & 16\end{array}$

$\begin{array}{ll}5.2 \text { Roman activity } & 17\end{array}$

$\begin{array}{ll}5.3 \text { Medieval activity } & 18\end{array}$

6. Summary . . . . . . . . . . . . . . . . . . . . . . . 19

7. Acknowledgements. . . . . . . . . . . . . . . . . . . . . . 19

8. Addendum: Recent Excavations at Newbridge by Nick Johnstone. . . . . . . . . . . . . . . . 20

$\begin{array}{ll}\text { 8.1 The excavated evidence } & 20\end{array}$

8.2 The pot and its contents by George Haggarty \& Jackaline Robertson 21

$\begin{array}{ll}8.3 \text { Acknowledgements } & 25\end{array}$

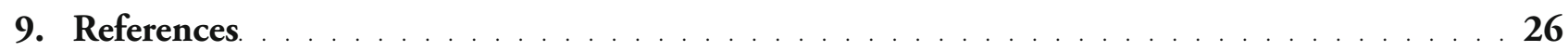


1. Site location showing other sites mentioned in the text

2. Chronological distribution of the later prehistoric dates

3. Overall plan of the excavation area, showing zones and topography

4. Zone 1: Middle Bronze Age structures

5. Zone 2: later prehistoric and Roman features

6. Plan and section of the fire-pit

7. Work in progress on the Roman road, looking east 9

8. The Roman road looking north-west $\quad 10$

9. N/S section through the Roman road 11

10. Chronological distribution of the Medieval dates 12

11. Zone 3: Medieval features 12

12. Plan of all excavated Medieval features 20

13. Vessel 1: a) in situ and b) after conservation $\quad 22$

14. Vessels 1 and $2 \quad 23$

15. Vessels 3-6 24

LIST OF TABLES

1. Prehistoric radiocarbon dates $\quad 5$

2. Medieval radiocarbon dates 13 
Excavations in advance of a phased commercial development have revealed a palimpsest of activity spanning the Middle Bronze Age to the Medieval period. There was a scatter of domestic settlement in the Middle Bronze Age and pre-Roman Iron Age, together with small ring-groove features which may be the remnants of a barrow cemetery forming part of a later prehistoric ritual landscape centred on Huly Hill.

Perhaps the most significant discovery of these excavations is the identification of a section of Roman road which probably represents the westward extension of Dere Street linking Inveresk and Carriden. Its discovery provides solid evidence for the routeway that the milestone at Ingliston and the temporary camps at Gogar have always intimated.

Finally, the area was farmed in the Medieval period, the associated settlement probably lying to the north of the excavated area. The dating evidence suggests two distinct phases of activity, in the 11th to 12 th centuries and in the 13 th to 14 th centuries, a pattern reflected in other Medieval settlement in the Lothians.

\section{INTRODUCTION}

This report presents the results of archaeological excavations commissioned by Gordon Murray \& Alan Dunlop Architects on behalf of clients Rooster II LLP. The excavations were undertaken by AOC Archaeology Group in 2007, prior to the phased commercial development of an 18 ha site (centred on NGR: NT 121733 ) situated to the immediate north of Edinburgh Road, and to the west of the M9 motorway, and bounded to the north and west by the River Almond (Illus 1).

Archaeological watching briefs were employed across the northern and western parcels of the site

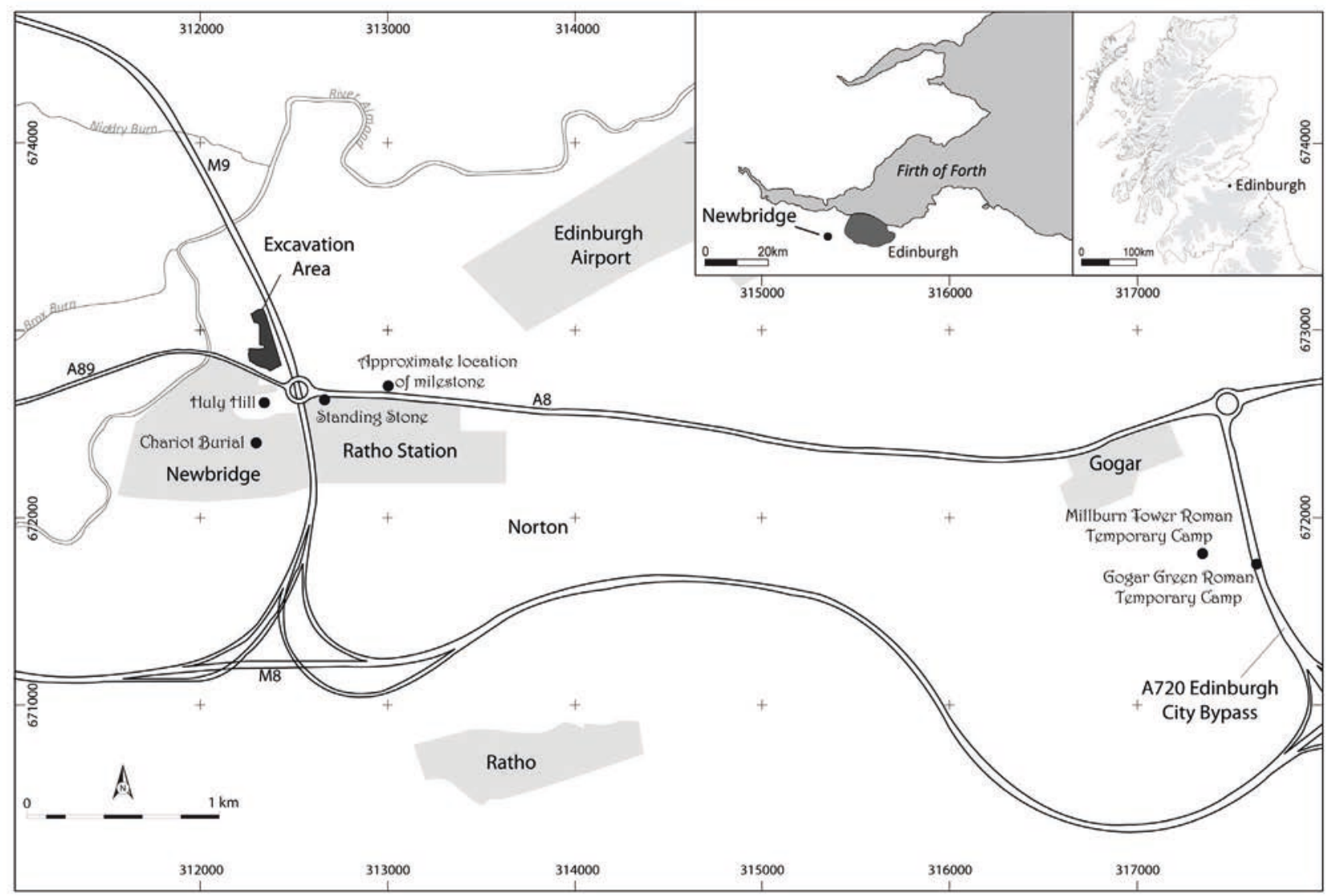

Illus 1 Site location showing other sites mentioned in the text 
over the footprint of a former poultry farm, but in the southern half of the site, which was primarily arable, and where archaeological features had been recorded during the evaluation, the methodology employed was that of 'strip, map and sample'. The topsoil was removed using a $360^{\circ}$ excavator down to the level of the first significant archaeological horizon or to drift deposits as appropriate. The features were then recorded and mapped, and subsequently excavated by hand. Bulk soil samples from all excavated features were taken for the retrieval of ecofactual and artefactual evidence.

All the archaeological features recorded here were encountered in arable fields in the south-eastern portion of the development area. However, it is important to note that the northern parcels of the area have not yet been fully investigated because of the phased nature of the development programme and that, as a consequence, a more complete archaeological landscape than the one presented below may still survive at Newbridge (see Addendum).

The results of the excavations are presented below by phase. Despite extensive palaeoenvironmental sampling, charred macroplant material was relatively sparse (Robertson 2011) and this in turn hampered the number of taphonomically secure radiocarbon dates that could be obtained

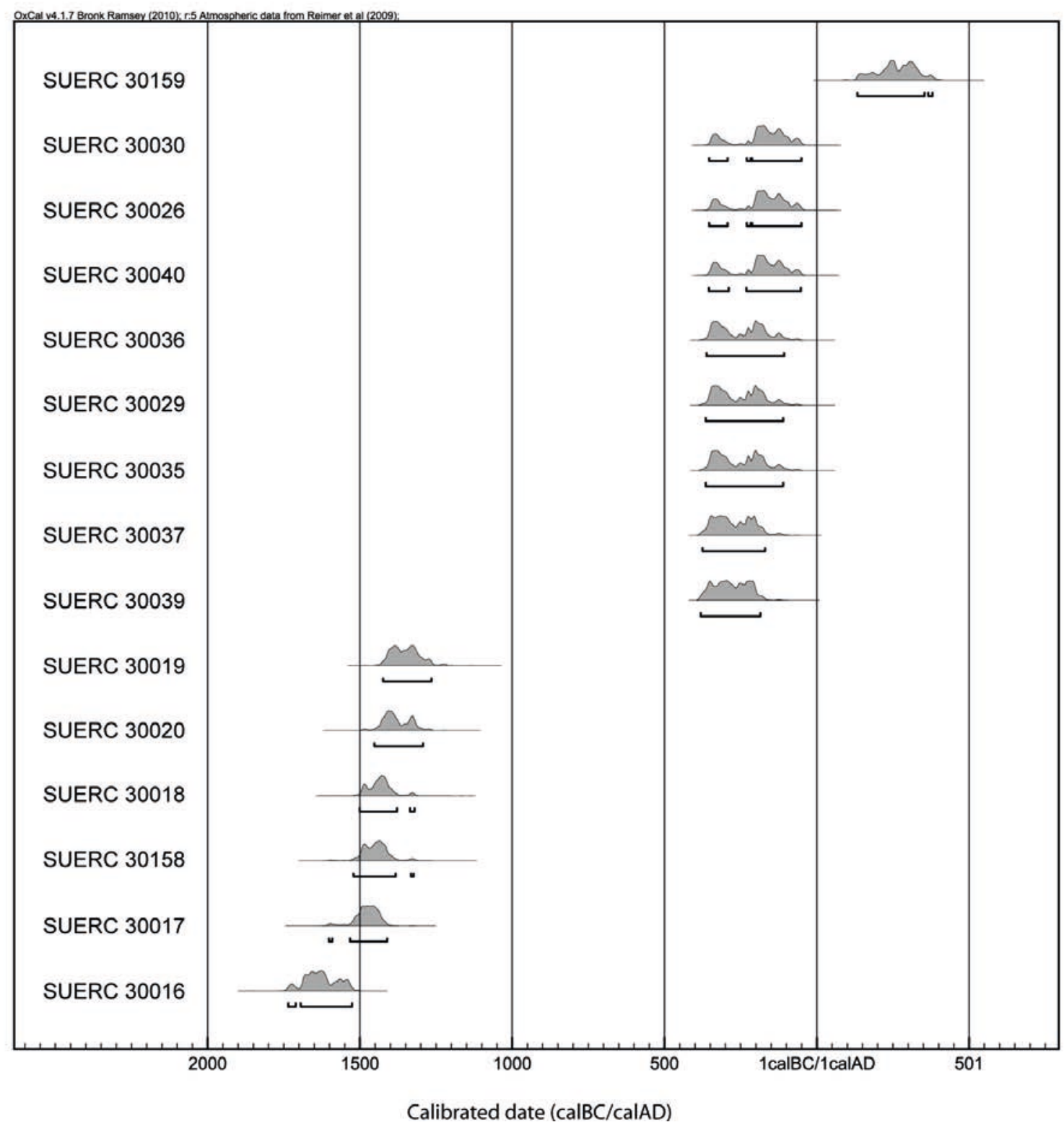

Illus 2 Chronological distribution of the later prehistoric dates 


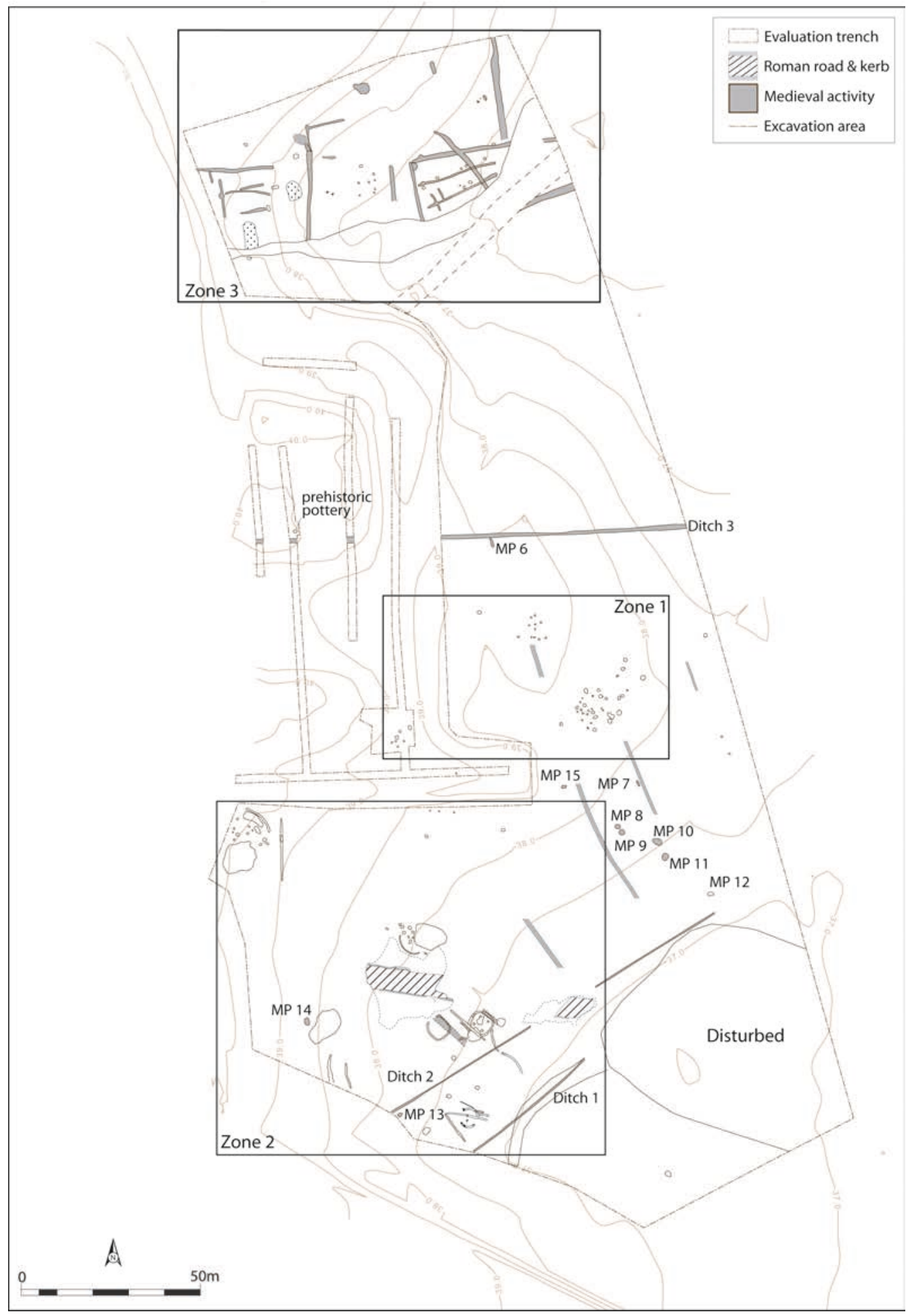

Illus 3 Overall plan of the excavation area, showing zones and topography

from the assemblage. The phasing of the excavated features is therefore based on a relatively small number of radiocarbon dates (quoted at 2-sigma throughout the text - and see Tables $1 \& 2$; Illus 2 $\& 10$ ), a small artefact assemblage and the overall morphology of some of the structures and/or their proximity to firmly dated structures. There were many isolated features, particularly in Zone 2 (Illus 3) which could not be dated in this way; these are not reported on in this paper. Apart from a pit of possible Mesolithic date, the main phases of activity occurred in the Middle Bronze Age, the pre-Roman Iron Age, the Roman period and the Medieval period. 


\section{PREHISTORIC AND ROMAN ACTIVITY}

\subsection{Summary of the environmental evidence}

A very sparse macroplant and charcoal assemblage was recovered from the prehistoric and Roman features (Robertson 2011). The macroplant assemblage comprised poorly preserved cereal caryopses, most of it unidentifiable as to species. Species that could be identified included oat (Avena sp), barley (Hordeum sp) and bread/club wheat (Triticum aestivum/ compactum $\mathrm{L}$ ), as well as chaff fragments. Oak (Quercus sp), hazel (Corylus avellana $\mathrm{L})$, birch (Betula sp), alder (Alnus glutinosa) and pomaceous fruits (ie apple, pear, hawthorn, quince) were present as charred remains.

\subsection{Summary of the artefactual evidence}

A small assemblage consisting of 41 sherds of chronologically undiagnostic character was recovered from the site, all but three of the sherds coming from pits and post-holes within Structure 1 (MacSween 2010). The other three sherds came from an isolated pit uncovered in one of the evaluation trenches (Illus 3). Most were body sherds, although there was a fragment from a flat rim and a possible base fragment. Most of the sherds have sooting, suggesting that they derive from cooking vessels.

A small number of lithics and coarse stone were also retrieved. The former consisted of single flakes of burnt flint, chalcedony and chert, while the coarse stone included a shale pot-lid and a small quartz polisher.

\subsection{Mesolithic activity}

P1, a pit in the north of the excavation area (Illus 11) produced a Mesolithic date of $6640-6230 \mathrm{cal} \mathrm{BC}$ (Table 1; SUERC-30038). The pit was sub-circular in plan, measuring $1.2 \mathrm{~m}$ by $1.1 \mathrm{~m}$, with a broad Ushaped profile and flat base. There were two fills in the pit, the upper of which contained charcoal and fire-cracked stone; the date came from charcoal from this fill. However, the pit is situated in the midst of a fragmentary Medieval landscape (see below) and there is no other evidence of Mesolithic activity in the vicinity. It therefore remains a possibility that the charcoal is residual; contamination of other features has also been noted (see below).

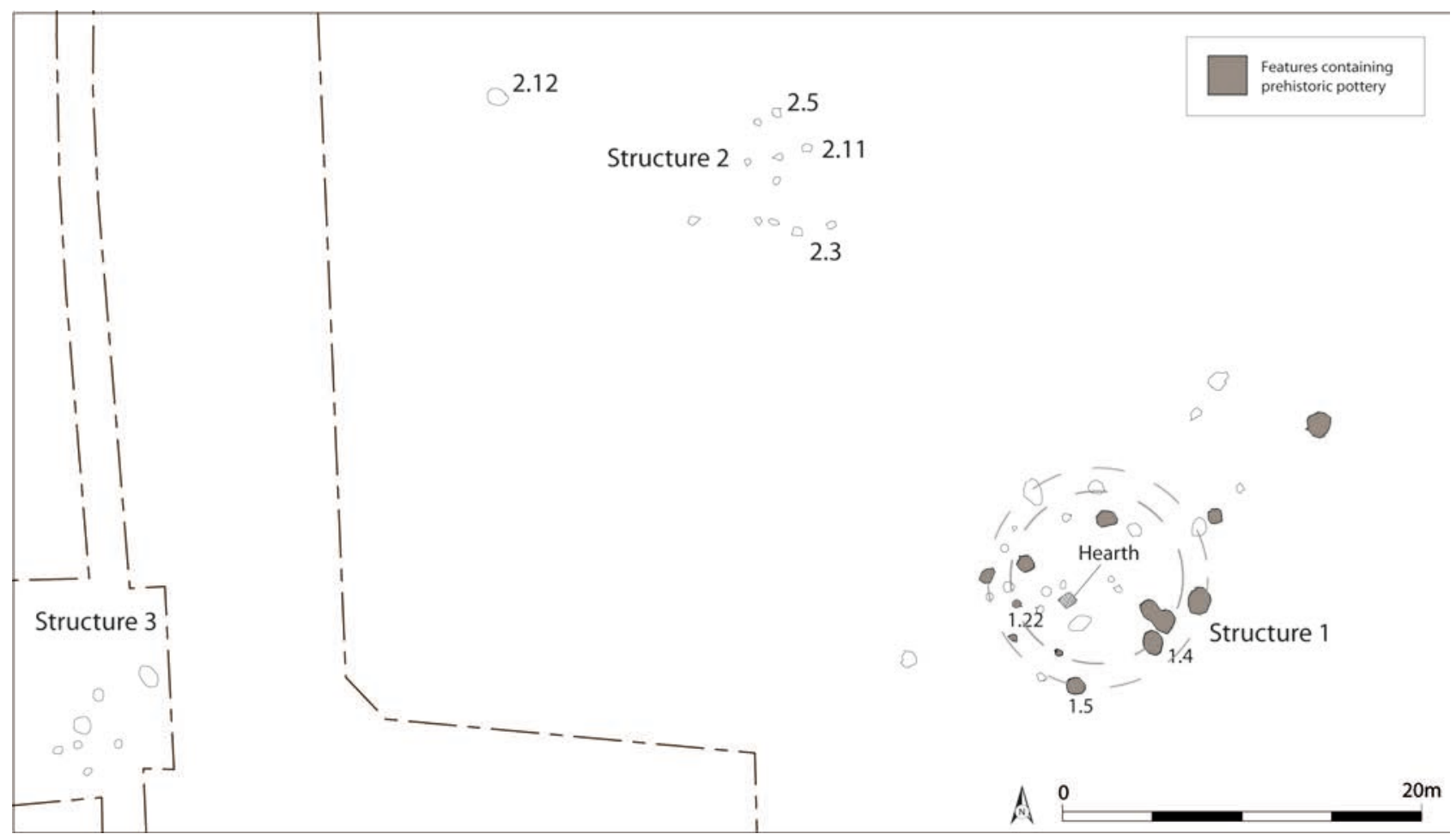

Illus 4 Zone 1: Middle Bronze Age structures 


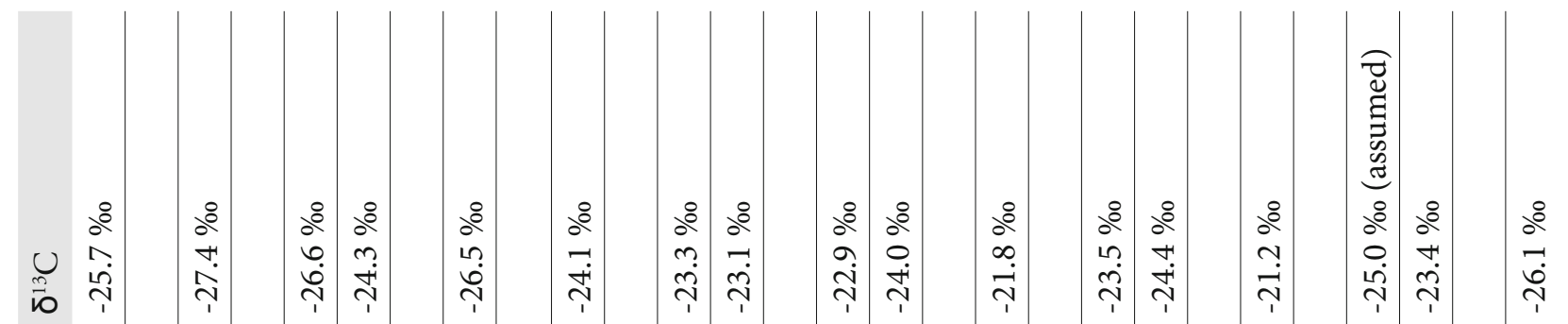

శ్త్రీ

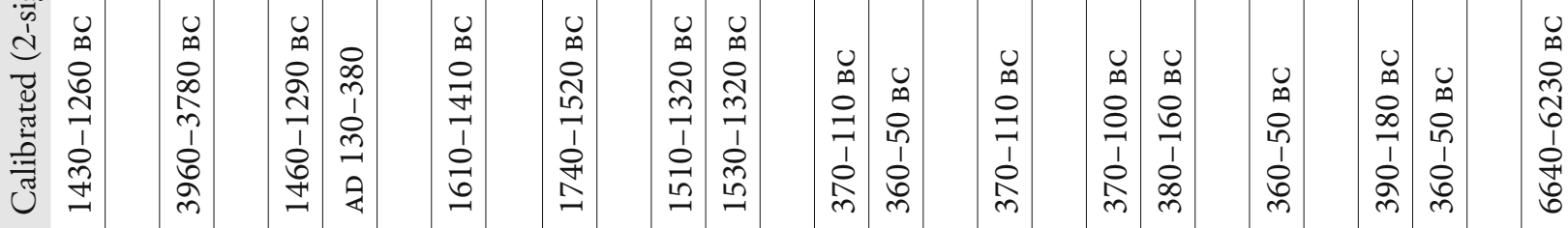

:

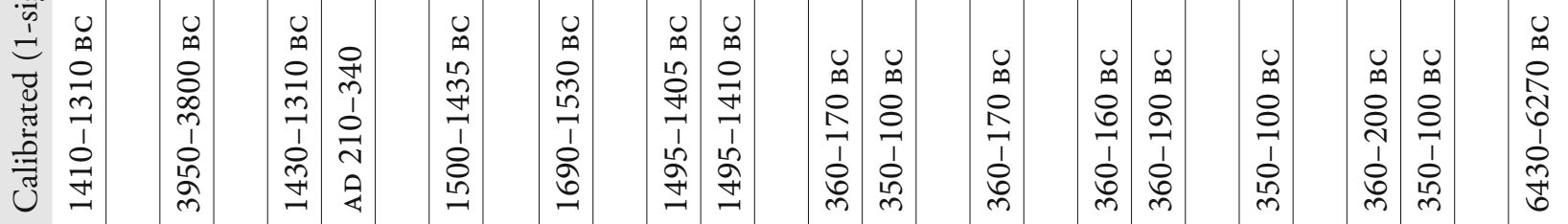

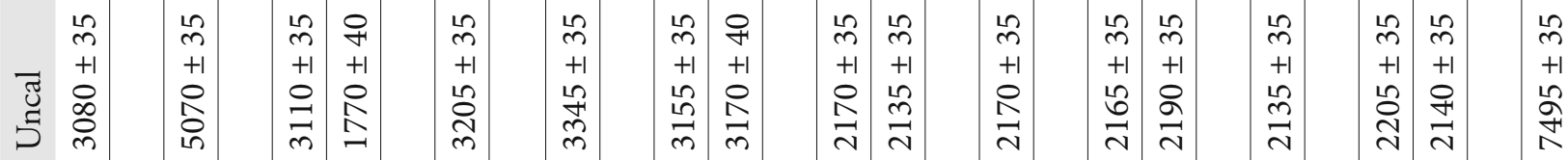

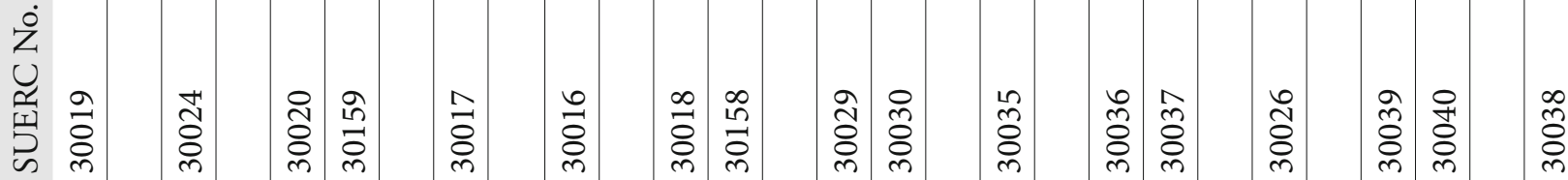

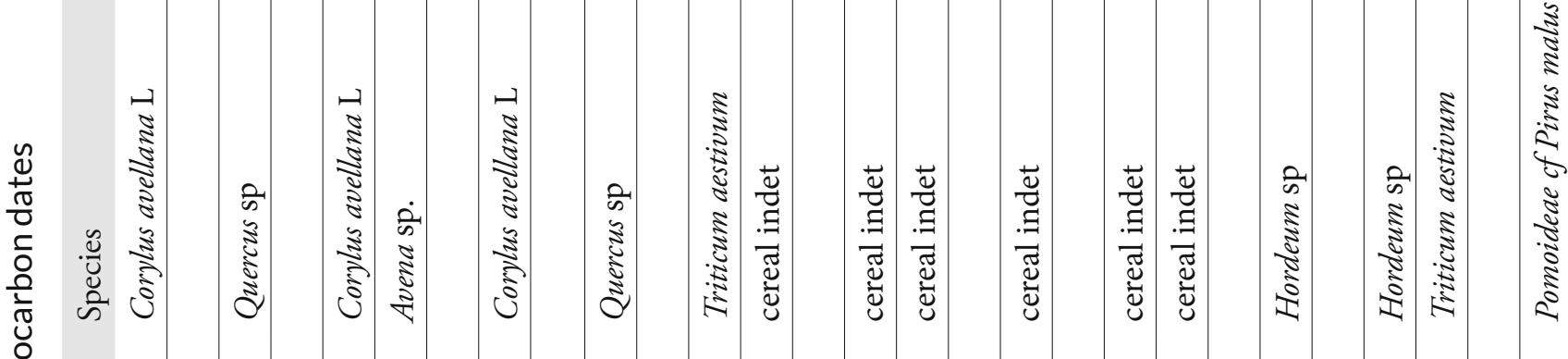

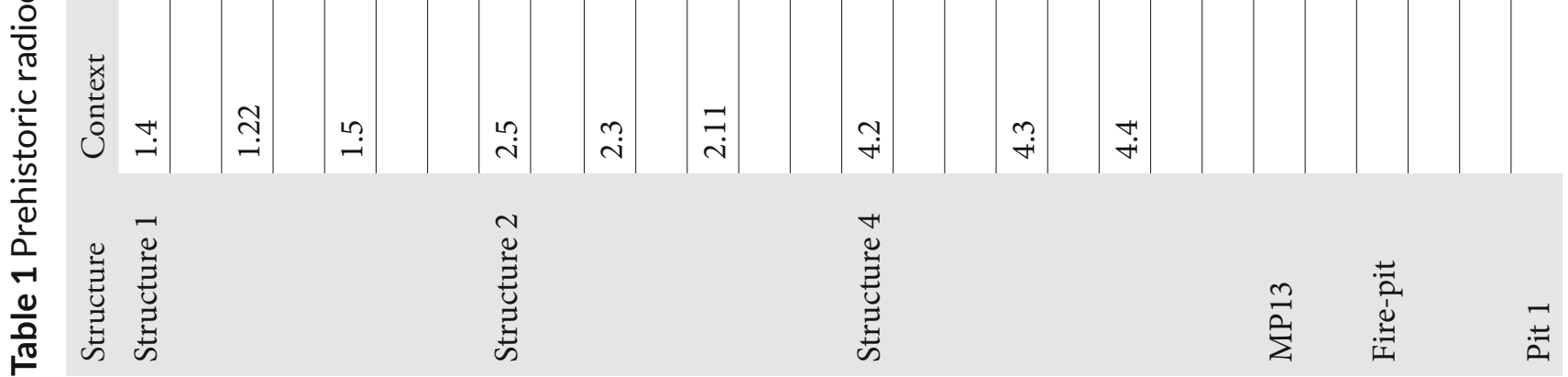




\subsection{Middle Bronze Age activity}

All the structures of this phase are located within Zone 1 (Illus $3 \& 4$ ).

\subsubsection{Structure 1}

Structure 1 consists of 25 pit and post-hole features arranged in two roughly concentric circles, forming a roundhouse $10 \mathrm{~m}$ in diameter (Illus 4 ). The postholes ranged from $0.30 \mathrm{~m}$ to $0.90 \mathrm{~m}$ in diameter, and had depths ranging from $0.23 \mathrm{~m}$ to $0.50 \mathrm{~m}$. In general the features identified as pits tended to be larger in size with dimensions ranging from $1.22 \mathrm{~m}$ to $2.21 \mathrm{~m}$ in length and $0.85 \mathrm{~m}$ to $1.33 \mathrm{~m}$ in width. These pits were up to $0.50 \mathrm{~m}$ in depth. The figureof- 8 shaped pit on the south-eastern side of the structure could be a re-cut or replaced post-hole. A scatter of five pit and post-hole features lie just to the north-east of Structure 1 and may form an ancillary structure of some sort.

A hearth lay slightly off-centre within the structure. It was constructed from a series of stone slabs set on edge and measured $0.75 \mathrm{~m}$ by $0.6 \mathrm{~m}$. It was up to $0.25 \mathrm{~m}$ deep and was filled with dark brown silty sand with trace amounts of charcoal and burnt bone.

Roundhouse 1 produced four radiocarbon dates (Table 1). Features 1.4 and 1.5 produced Middle Bronze Age dates of 1430-1260 cal вс (SUERC30019) and 1460-1290 cal вс (SUERC-30020) respectively. However, 1.5 also produced a much later date of cal AD 130-380 (SUERC-30159), while 1.22 also produced an Early Neolithic date of 3960-3780 cal вс (SUERC-30024) from a fill (583) that also produced later prehistoric pottery. Given the morphology of Structure 1, the Middle Bronze Age dates are more likely to be contemporary with the construction of the building, the other two dates probably representing contamination.

Almost all of the prehistoric ceramics found during the excavation came from Structure 1. Sherds were recovered from 12 features, including one of the pits to the north-east of the structure. Unidentifiable fragments of burnt bone were also observed in the fills of many of the same features.

\subsubsection{Structure 2}

Structure 2 consists of a group of 11 post-holes (Illus 4 ), which are likely to be the truncated remains of a post-built roundhouse like the more complete Structure 1 . The majority of the post-holes were relatively circular with an average diameter of $0.45 \mathrm{~m}$ and depths ranging from $0.15 \mathrm{~m}$ to $0.29 \mathrm{~m}$. They all had steeply sloping sides and narrow rounded bases. A pit to the north-west of this group [2.12] may be associated with this structure; it was $1.2 \mathrm{~m}$ by $1.0 \mathrm{~m}$ and $0.30 \mathrm{~m}$ deep, with steeply sloping sides and a flat base.

Post-holes 2.3 and 2.5 produced Middle Bronze Age dates of 1740-1520 cal вс (SUERC-30016) and 1610-1410 cal вС (SUERC-30017) respectively, while post-hole 2.11 produced two almost identical dates of 1510-1320 cal вс (SUERC-30018) and 1530-1320 cal вс (SUERC-30158) (Table 1).

\subsubsection{Structure 3}

Structure 3 consisted of a cluster of seven pit and post-hole features (Illus 4). The post-holes ranged in diameter from $0.40 \mathrm{~m}$ to $0.80 \mathrm{~m}$ with a maximum depth of $0.45 \mathrm{~m}$. There was a much larger pit within the centre of the cluster which was $1.02 \mathrm{~m}$ by $0.70 \mathrm{~m}$ but only $0.12 \mathrm{~m}$ deep. No artefacts or ecofacts were recovered from this group of features but it seems most likely that it is another truncated roundhouse like its nearest neighbours, Structures 1 and 2.

\subsection{Pre-Roman Iron Age activity}

All the features of this phase are concentrated in Zone 2 (Illus $3 \& 5$ ).

\subsubsection{Structure 4}

This small circular structure is $6 \mathrm{~m}$ in diameter (Illus 5). It consists of an almost circular ring-groove within which are four equally spaced post-holes $[4.1,4.2,4.3 \& 4.4]$. The post-holes were between $0.55 \mathrm{~m}$ and $0.60 \mathrm{~m}$ in diameter and all displayed sharp, U-shaped profiles with narrow rounded bases. One of the post-holes had been truncated by a large oval pit measuring $2.55 \mathrm{~m}$ in length by $1.62 \mathrm{~m}$ in width. This pit was $0.30 \mathrm{~m}$ in depth and contained moderate inclusions of small to large sub-rounded and angular stones. 


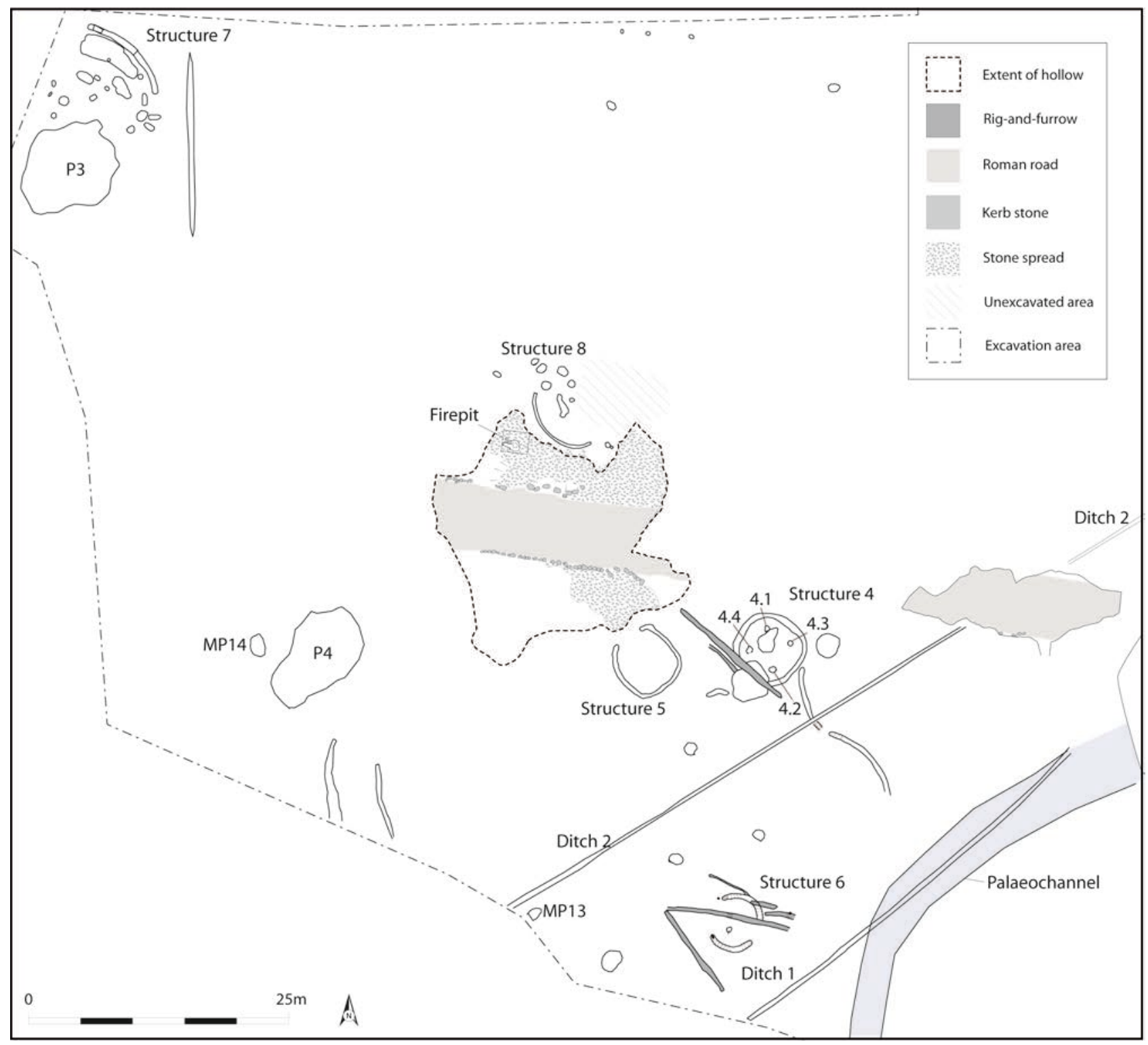

Illus 5 Zone 2: later prehistoric and Roman features

The ring-groove varied from $0.35 \mathrm{~m}$ to $0.54 \mathrm{~m}$ in width, was up to $0.20 \mathrm{~m}$ deep and had gently sloping sides and a flat base. The entrance may lie on the south-west side, which had been truncated by a later linear ditch. A spread of grey clay containing small pebbles, $2.0 \mathrm{~m}$ by $1.5 \mathrm{~m}$ across, lay over the possible entrance.

Charcoal from three of the post-holes within Structure 4 produced a series of Iron Age dates, which, when calibrated, are statistically indistinguishable from each other (Table 1) and indicate activity sometime in the 4th to 1 st centuries BC (SUERC30029-30, 30035-7). One of the post-holes [4.3] also produced a Medieval date (SUERC-30035 - and see below) which must represent later contamination.
Just outside the structure to the east was a large pit, $2.35 \mathrm{~m}$ in diameter and $0.67 \mathrm{~m}$ deep, filled with grey clay with occasional large stones and flecks of burnt bone. Its close juxtaposition to Structure 4 suggests they may be associated.

\subsubsection{Structure 5}

All that survives of this structure is a circular ringgroove, approximately $6 \mathrm{~m}$ in diameter, with an opening $2 \mathrm{~m}$ to the north-west which might be the entrance (Illus 5), although this area has been truncated by later cultivation furrows. The ringgroove varied in width from $0.26 \mathrm{~m}$ to $0.36 \mathrm{~m}$ and was up to $0.16 \mathrm{~m}$ deep. It had a steeply sloping 
U-shaped profile with a narrow, rounded base ending in two rounded terminals. No datable evidence was recovered but it is very similar in size and form, and immediately adjacent to, Structure 4 , so is ascribed a similar date.

\subsubsection{Structure 6}

Structure 6 consists of two apparently separate curvilinear ring-grooves forming a circle approximately $5.6 \mathrm{~m}$ in diameter (Illus 5). The ring-grooves were approximately $0.50 \mathrm{~m}$ in width and had steeply sloping sides and rounded bases. A single post-hole lay just off-centre within the structure. As with Structure 5, no datable material was recovered from this structure but, again, its form and size are similar to dated Structure 4. A barley grain from MP13, a pit lying some $17 \mathrm{~m}$ to the west of Structure 6, did produce an Iron Age date of 360-50 cal (Table 1; SUERC-30026), very similar to the dates from Structure 4, but it also produced Medieval pottery, so the grain could be residual in this context.

\subsubsection{Structure 7}

Structure 7 was only partially investigated because it extended west beyond the limit of excavation, while a large quarry pit, $\mathrm{P} 3$, truncated the structure to the south (Illus 5). The visible remains within the excavation area consisted of a ring-groove, an erosional gully, 13 post-holes and two internal pits. The ring-groove survived for a length of $8 \mathrm{~m}$ and defined a structure approximately $12 \mathrm{~m}$ in diameter. It was $0.50 \mathrm{~m}$ in width with steeply sloping, almost vertical sides and a rounded base $0.20 \mathrm{~m}$ in depth. The erosional gully lay just within the ring-groove; it was $5.50 \mathrm{~m}$ in length and was up to $2 \mathrm{~m}$ wide and $0.50 \mathrm{~m}$ deep, with gently sloping sides and a flat, irregular base.

The post-holes ranged from $0.25 \mathrm{~m}$ to $0.90 \mathrm{~m}$ in diameter with a maximum depth of $0.30 \mathrm{~m}$. Both pits were oblong in shape, between $1.80 \mathrm{~m}$ and $2.0 \mathrm{~m}$ in length, with widths of $0.90 \mathrm{~m}$ and depths of $0.21 \mathrm{~m}$. No dating evidence, artefactual or ecofactual, was recovered from Structure 7.

The remains of a narrow linear feature on a north/ south alignment ran past the structure to the east. Given the absence of any other features in this area of the site, it seems likely that it is associated with Structure 7 and represents a boundary ditch.

\subsubsection{Structure 8}

Structure 8 was only partially excavated because the area around an active telegraph pole had to be left unexcavated (Illus $5 \& 7$ ). It consists of a ring-groove which would have defined a structure approximately $12 \mathrm{~m}$ in diameter and a cluster of associated pits and post-holes (Illus 5). The ring-groove had survived for a length of $6 \mathrm{~m}$ and was $0.30 \mathrm{~m}$ wide and $0.23 \mathrm{~m}$ deep, with near vertical sides and a rounded base. Within the ring-groove was an oblong pit $2.10 \mathrm{~m}$ long, up to $0.65 \mathrm{~m}$ wide and $0.25 \mathrm{~m}$ deep with steeply sloping sides and a rounded base. Most of the associated pit and post-hole features were truncated features, no more than $0.20 \mathrm{~m}$ in depth and varying in width/ diameter from $0.55 \mathrm{~m}$ to $1 \mathrm{~m}$. There were two better preserved post-holes with diameters of $0.45 \mathrm{~m}$ and depths of $0.40 \mathrm{~m}$.

Although no datable evidence was recovered from Structure 8, it is clearly respected by the stone-filled hollow which appears to form an apron around the southern half of the structure (Illus 7). A fire-pit was cut into the hollow just to the south-east of Structure 8 and this produced Iron Age radiocarbon dates (Table 1; SUERC-30039 \& SUERC-30040). Given the spatial and stratigraphic relationships between this complex of features, it is probable that Structure 8 is also Iron Age in date. These associated features are described below.

\subsubsection{The stone-filled hollow}

The hollow may have been natural in origin but it has subsequently undergone modification, particularly along its eastern edge (Illus 5). It was asymmetric in shape with maximum dimensions of $21 \mathrm{~m}$ by $19 \mathrm{~m}$. It was up to $0.70 \mathrm{~m}$ deep in places and had gently sloping edges and a flat base. The northern half of the hollow was filled by a primary deposit of small water-worn cobbles, $0.10 \mathrm{~m}$ deep, which was overlaid by a layer of larger sub-rounded stones, $0.20 \mathrm{~m}$ deep, which in places appears to form a paved surface (Illus 8). A patch of stones had survived in the southern tip of the hollow.

As described above, the hollow clearly respects Structure 8, so it may represent a working platform 

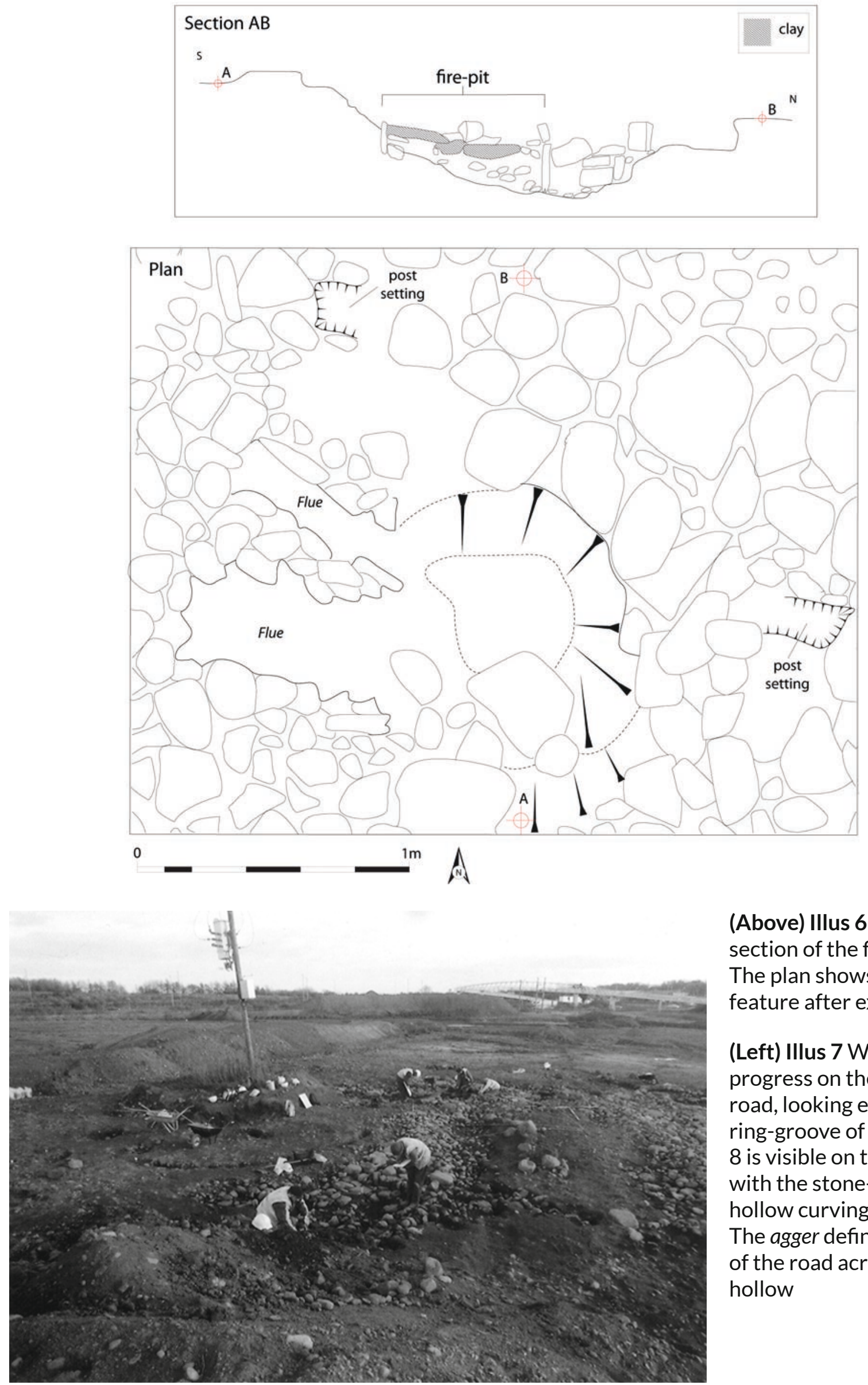

(Above) Illus 6 Plan and section of the fire-pit. The plan shows the feature after excavation

(Left) Illus 7 Work in progress on the Roman road, looking east. The ring-groove of Structure 8 is visible on the left, with the stone-filled hollow curving around it. The agger defines the line of the road across the hollow 


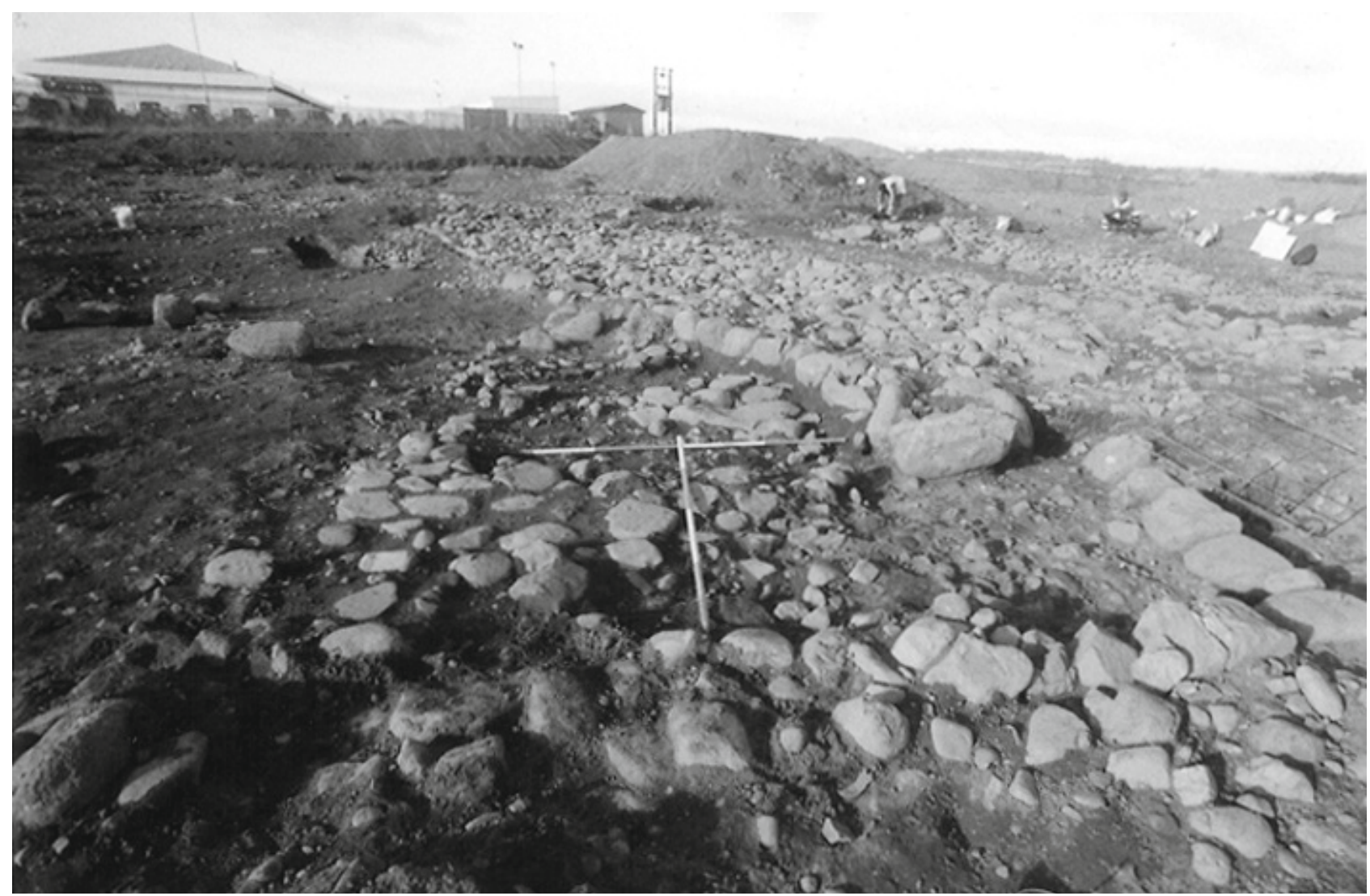

Illus 8 The Roman road looking north-west, with the southern kerb visible and the stones of the hollow extending south beyond it

associated with this structure. Several features had been cut into the matrix of the hollow; these may relate to its function.

A fire-pit (Illus 5 \& 6) had been constructed by digging a pit through the matrix of the hollow, $0.90 \mathrm{~m}$ by $1.75 \mathrm{~m}$ and $0.55 \mathrm{~m}$ in depth. A box-like structure, $0.90 \mathrm{~m}$ by $0.60 \mathrm{~m}$ and $0.25 \mathrm{~m}$ deep, was constructed within the pit using thin slabs of sandstone placed on edge. The box was lined with clay and contained a fill of dark brown sandy silt.

To the west and north-west two flues extended from the fire-box, also cut through the matrix of the hollow and lined with thin slabs of sandstone. The western flue was $0.40 \mathrm{~m}$ across while the northwestern flue was only $0.20 \mathrm{~m}$ across. The exact relationship between the flues and the fire-box is unclear and it is possible that they represent remodelling of the structure. There are two possible post-settings to the east and north of the fire-pit, which may represent the remains of an associated structure.

Radiocarbon dates of 390-180 cal вс (Table 1; SUERC-30039) and 360-50 cal вс (Table 1;
SUERC-30040) were recovered from the clay lining of the fire-box and the fill of one of the flues respectively, suggesting an Iron Age date for the structure.

Sealed below the western segment of the metalled surface, interpreted as a Roman road, was a large pit seen only in section. The pit was $2.10 \mathrm{~m}$ wide and $0.70 \mathrm{~m}$ deep and was completely filled by very large sub-rounded boulders. No finds or macroplant remains were recovered from the silty matrix. This feature may be related to the use of the hollow and was subsequently filled with stones prior to the construction of the road.

\subsubsection{Associated features}

Scattered between Structures 5 and 6 are four large pits which may be associated with the structures (Illus 5). They are generally circular in shape with diameters ranging from $0.98 \mathrm{~m}$ to $2.55 \mathrm{~m}$. One pit was oval in shape measuring $1.22 \mathrm{~m}$ by $0.50 \mathrm{~m}$. All the features had gently sloping sides and rounded bases. 


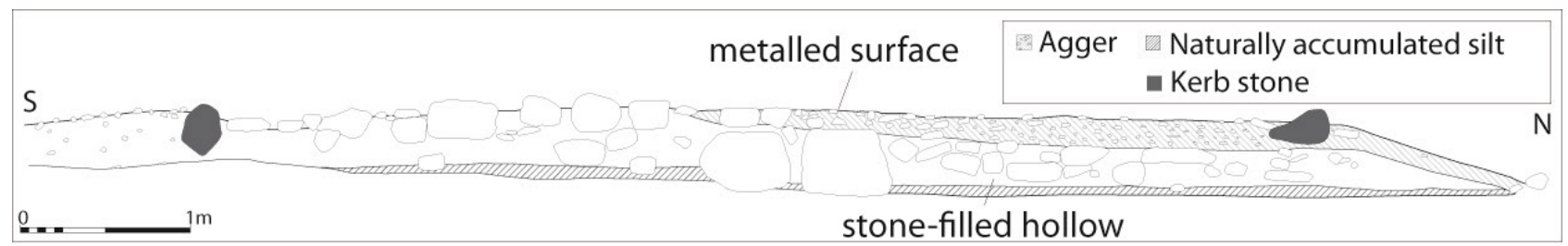

Illus 9 N/S section through the Roman road

There are also several curvilinear lengths of ditch, two to the east of Structure 4, and two which appear to lie parallel to each other and which continue beyond the southern limits of the excavation. These could be the very truncated remnants of ring-groove structures like Structures 4, 5 and 6.

\subsection{Roman activity}

Roman activity on the site is represented by the road and associated quarry pits (Illus 5). There are no radiocarbon dates or artefacts associated with these features but an oat grain from a pit in Structure 1, which is Middle Bronze Age in date, produced a much later date of cal AD 130-380 (Table 1; SUERC30159), which presumably reflects Romano-British activity in the vicinity.

Two discrete areas of road had survived within the excavation area, running WNW/ESE over a total distance of roughly $67 \mathrm{~m}$. Of the two areas, the western segment was considerably better preserved (Illus 8 \& 9). This segment was roughly $7 \mathrm{~m}$ wide and had survived for a length of $21 \mathrm{~m}$. It was flanked by kerbs which were constructed from large, locally derived, un-bonded stones, between 0.3 and $0.5 \mathrm{~m}$ across. The southern kerb was intact along the surviving length of the road but the northern kerb was discontinuous, and only a $9.5 \mathrm{~m}$ length had survived. This segment of the road ran over the stone-filled hollow and this had been used as a foundation deposit. A compact red brown silty sand $0.17 \mathrm{~m}$ in depth lay over the stones of the hollow (Illus 8 \& 9), which was in turn overlaid by a metalled surface which had only survived in patches.

The eastern segment of the road had been heavily truncated by Medieval and modern cultivation. It survived as a roughly diamond-shaped area $21 \mathrm{~m}$ long with a maximum width of $7 \mathrm{~m}$. Although lacking the larger foundation deposits provided by the stone infill of the hollow, the construction matrix was identical to the western segment. This consisted of a foundation of medium sub-rounded stones over which a compact brown silt with small stones and a metalling of gravel had been laid. This upper metalled surface survived in sparse patches. Only a short stretch of the southern kerb had survived, $3 \mathrm{~m}$ in length.

Two large pits, P3 and P4, may represent quarry pits associated with the construction of the road (Illus 5). P3 was roughly circular and measured $9 \mathrm{~m}$ by $6 \mathrm{~m}$ with a maximum depth of $0.70 \mathrm{~m}$. P4 was sub-oval and measured $10.69 \mathrm{~m}$ by $7 \mathrm{~m}$ with a depth of $0.75 \mathrm{~m}$. Both pits had U-shaped profiles and flat bases.

\section{MEDIEVAL ACTIVITY}

\subsection{Introduction}

The greatest density of Medieval features lay in the northern part of the site beyond the palaeochannel (Zone 3; Illus 3 \& 11). These features consisted of ditches, post-holes, pits, corn kilns and stone platforms. Apart from P1, which produced a Mesolithic date (see above) there is no evidence for earlier activity in this area and it is assumed that all the features, some of which are intercut, are part of a larger Medieval agricultural landscape.

Cutting across the prehistoric and Roman features in the southern half of the site were the vestigial remains of an extensive field system, which includes several major ditches and the remains of rig-andfurrow lying at right angles to the ditches (Illus $3 \&$ 5). Scattered across the field system were pits, some of which contained Medieval pottery. The features are described below by type. 


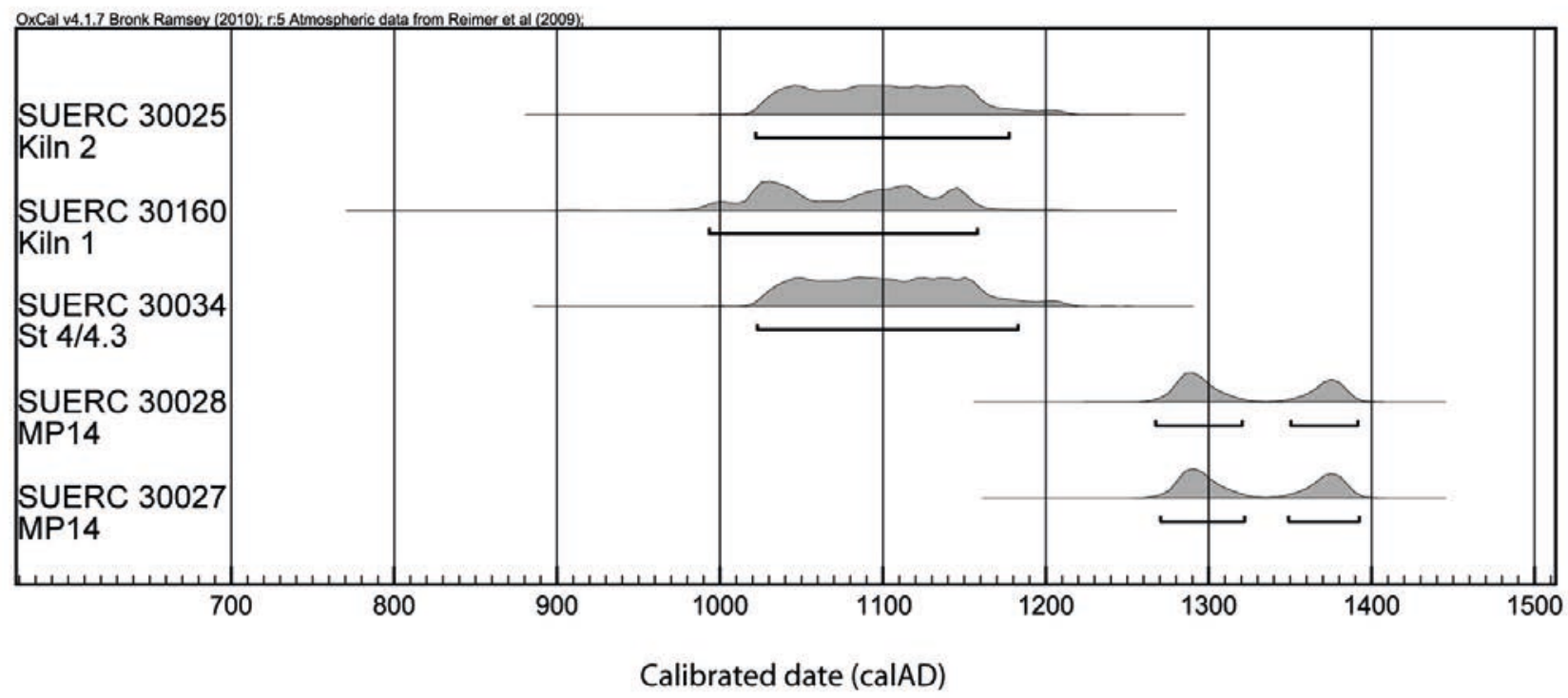

Illus 10 Chronological distribution of the Medieval dates

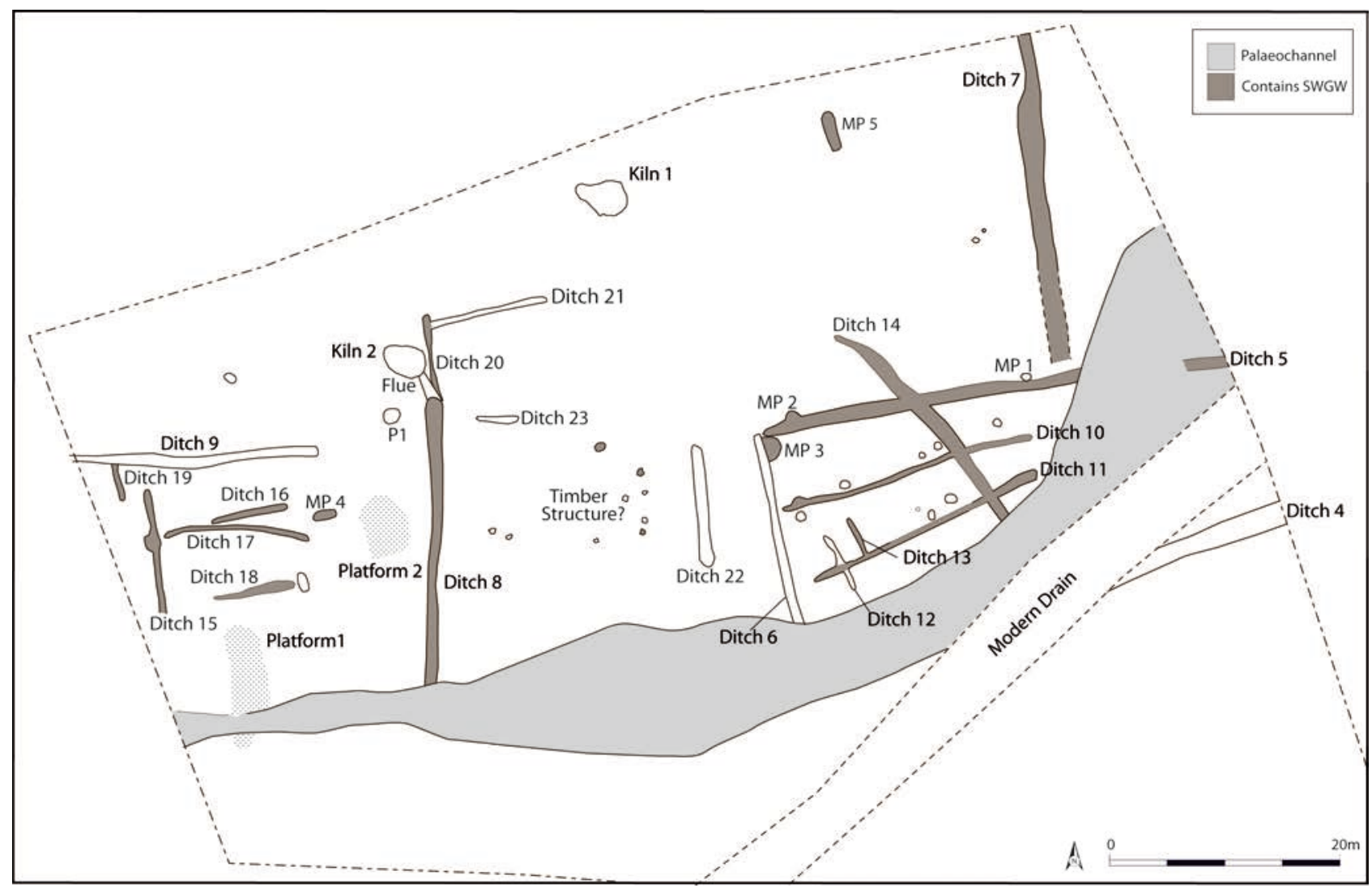

Illus 11 Zone 3: Medieval features 


\subsection{Dating evidence}

The radiocarbon dates indicate two distinct phases of Medieval activity. Dates on oat grains from Kilns 1 and 2 indicate activity sometime within the 11 th to 12th centuries AD (Table 2; SUERC-30025 \& SUERC-30160). Charcoal from a post-hole within the Iron Age Structure 4 produced a virtually identical date (Table 2; SUERC-30034); while this almost certainly represents contamination, it does also indicate some 11th-12th century activity in the southern half of the site. Cereal grains from a pit, MP14, in this part of the site (Illus 5) produced two identical dates, indicating activity sometime within the 13th-14th centuries AD (Table 2; SUERC$30027 \&$ SUERC-30028). It is therefore likely that some of the other undated features in this area, such as the small linear features and other pits, are also Medieval in date.

\subsection{Summary of the artefactual evidence}

The ceramic assemblage consists almost entirely of Scottish White Gritty Ware (SWGW) sherds of 12 th/13th-century date with some later 14 th/15thcentury sherds (Jones \& Haggarty 2011). Chemical and petrographic analysis of the SWGW suggests that it was produced locally, and that the production centre was different from that producing the pottery found at nearby Norton (Swan \& Carruthers 2006 - see Illus 1). The sherds, many of which were abraded, were found mainly in the features in the northern half of the site, in ditches, post-holes, pits, corn kilns and stone platforms. Sherds of SWGW were found in Ditch 2, in some of the pits scattered amongst the rig-and-furrow and in some of the pits near the south-west boundary of the site.

\subsection{Summary of the environmental evidence}

Preservation of macroplant remains was noticeably better in Zone 3 than elsewhere on the site. The remains were concentrated in the two kilns which both contained assemblages of cultivated oat, oat species, barley, bread/club wheat, wheat/rye and chaff (Robertson 2011). Other charred plant remains were pea and wild radish, the latter a common contaminent that grows alongside cultivated crops. The dominant cereal was oat. The small quantity of chaff present indicates that the crops had been processed prior to drying in the kilns. A similar but much sparser assemblage was also found in the ditches, pits and post-holes.

\subsection{Field systems and enclosures}

The northern part of the site is dominated by a multitude of linear ditch features (Illus 11). There are 20 ditches of varying length, width, depth and orientation. While there were numerous instances of ditches intercutting, it was impossible to differentiate or distinguish the fills and thus it was impossible to determine whether one ditch predated another.

Table 2 Medieval radiocarbon dates

\begin{tabular}{|c|c|c|c|c|c|c|}
\hline Structure & Species & SUERC No. & Uncal & $\begin{array}{l}\text { Calibrated } \\
\text { (1-sigma) }\end{array}$ & $\begin{array}{l}\text { Calibrated } \\
\text { (2-sigma) }\end{array}$ & $\delta^{13} \mathrm{C}$ \\
\hline Kiln 1 & Avena sp & 30160 & $975 \pm 40$ & $\mathrm{AD} 1010-1160$ & AD 990-1160 & $-23.8 \%$ o \\
\hline Kiln 2 & Avena sp & 30025 & $935 \pm 35$ & AD $1030-1160$ & AD $1020-1180$ & $-24.4 \%$ \\
\hline Structure $4 / 4.3$ & cereal indet & 30034 & $930 \pm 35$ & AD $1030-1160$ & AD $1020-1190$ & $-22.0 \%$ \\
\hline \multirow[t]{2}{*}{ MP14 } & Triticum sp & 30027 & $675 \pm 35$ & AD $1270-1390$ & AD $1260-1400$ & $-23.1 \% 0$ \\
\hline & cereal indet & 30028 & $680 \pm 35$ & AD $1270-1390$ & AD $1260-1400$ & $-26.1 \%$ \\
\hline
\end{tabular}




\subsubsection{Enclosures}

The most substantial ditches were on two distinct alignments, Ditches 6, 7 and 8 north to south, and Ditches 4, 5 and 9 east to west, and these probably formed rectilinear enclosures or fields. Ditches 4, 5 and 6 could form a large rectangular enclosure (the eastern enclosure), with Ditch 7 forming one side of an adjoining enclosure. Ditches 8 and 9 could form the north-east corner of another large enclosure (the western enclosure). These larger enclosure ditches are generally just less than $1.0 \mathrm{~m}$ wide and $0.40 \mathrm{~m}$ deep on average, commonly with a U-shaped profile. Their full extents are unknown, so we can only guess at the size of the fields they defined. All of these ditches contained a single homogeneous fill, except for Ditch 5, which had been recut with steep sides that were stone-lined in places. Sherds of SWGW were recovered from Ditches 5, 7 and 8. The carbonised remains of oats, barley, bread/club wheat and wheat/ rye were also recovered from some of the ditches.

These larger enclosures appear to be subdivided by smaller ditches. In the eastern enclosure Ditches 10 and 11 run east/west and roughly parallel to the larger outer ditches, and were nearly identical in scale and length. Ditch 10 measured $22.5 \mathrm{~m}$ long by up to $0.49 \mathrm{~m}$ wide with a maximum depth of $0.18 \mathrm{~m}$, while Ditch 11 measured $20.2 \mathrm{~m}$ long by up to $0.67 \mathrm{~m}$ wide with a maximum depth of $0.18 \mathrm{~m}$. A number of post-holes lie along the northern edge of these ditches, and further subdivisions appear to have been created by short lengths of ditch, Ditches 12 and 13, extending north and south from Ditch 11 . These short ditches were of a very similar scale to Ditch 11 and their respective fills were indistinguishable. Sherds of SWGW were recovered from Ditches 10, 11 and 13.

Cutting across the eastern enclosure on a quite different alignment is Ditch 14 . This ditch is aligned roughly north-west/south-east and is of a similar scale to the larger enclosure ditches. The exact relationship between Ditch 14 and the ditches that it crosses could not be distinguished; Ditch 14 also contained charred material and SWGW pottery like the ditches it crosses, but this could be residual material in a later construction or, equally, intrusive material in an earlier feature.

The western enclosure was also subdivided by smaller ditches. Ditch 15 was aligned north/south, while Ditches 16, 17 and 18 were orientated east/ west. As with the subdividing ditches within the eastern enclosure, these ditches were slighter and shallower than the enclosure ditches, with depths between $0.09 \mathrm{~m}$ and $0.18 \mathrm{~m}$. Ditch 15 was $11.0 \mathrm{~m}$ in length while the three east/west ditches measured 12.9m for Ditch 17, 6.9m for Ditch 16 and $5.2 \mathrm{~m}$ for Ditch 18. All four ditches contained sherds of SWGW. Other features within the western enclosure include a small section of ditch, Ditch 19, which extended south from Ditch 9. Ditches 20 and 21 could form an adjoining enclosure, Ditch 20 extending the line of Ditch 8 north for about $5.0 \mathrm{~m}$, while Ditch 21 extends eastwards for more than $12.5 \mathrm{~m}$.

Between the two enclosures were other lengths of ditch. Ditch 22 was a substantial ditch, parallel to enclosure Ditch 6. It was nearly $6.0 \mathrm{~m}$ long by over $0.50 \mathrm{~m}$ wide but, unlike the enclosure ditches, it was quite shallow, with a maximum depth of only $0.11 \mathrm{~m}$, and it petered out to the south. Ditch 23 was a narrow ditch aligned east/west, from which two sherds of a SWGW jug were recovered.

\subsubsection{Fields}

In the southern half of the site there is a group of features which may form part of a larger field system (Illus 3). Ditch 3 is a substantial land boundary which lies some $85 \mathrm{~m}$ south of the enclosures described above (in Zone 3). It lies parallel with these enclosures running from east to west across the excavation area. It varied in width from $1.02 \mathrm{~m}$ to $0.74 \mathrm{~m}$ along its length and was at least $0.50 \mathrm{~m}$ deep, its profile a steeply sloping V-shape. No finds were retrieved from its single fill, but the only feature adjacent to the ditch, a long, narrow pit, MP6 (Medieval Pit 6) (Illus 3), yielded a sherd of SWGW.

Further south are two parallel lengths of ditch, which also form substantial landscape boundaries but which lie on a different alignment to Ditch 3 . Ditches 2 and 1 cut across the concentration of prehistoric features and the Roman road. They are aligned north-east/south-west and lie approximately $20 \mathrm{~m}$ from each other. Ditch 1 extends for more than $40 \mathrm{~m}$ and has a U-shaped profile with near-vertical sides, $0.40 \mathrm{~m}$ wide and $0.39 \mathrm{~m}$ deep. Although welldefined, Ditch 2 was quite shallow, with depths no greater than $0.20 \mathrm{~m}$ and widths varying between 
$0.40 \mathrm{~m}$ and $0.58 \mathrm{~m}$. A sherd of SWGW was recovered from the ditch. Between Ditches 2 and 3 are a series of shallow linear features aligned NNW/SSE, which may represent field ditches subdividing the area between the two major ditches.

\subsubsection{Rig-and-furrow}

In Zone 2 the ephemeral remains of six shallow linear features were recorded. They were all aligned NNW/SSE and measured between $1.3 \mathrm{~m}$ and $1.6 \mathrm{~m}$ wide. No finds were recovered from these features but they overlay and truncated the prehistoric Structures 4 and 5. Given the parallel alignment of the clusters and the fact that they lie on either side of Ditches 1 and 2, they have been interpreted as the remains of rig-and-furrow agriculture contemporary with the Medieval field system formed by Ditches 1 and 2 .

\subsection{Pits}

Scattered in and around the field system and enclosures were numerous pits, at least some of which are related to the Medieval activity. A deep pit, MP1, had been cut into the side of Ditch 5, possibly to act as a sump to aid drainage (Illus 11). Another pit, MP2, was located at the western end of Ditch 5, while pit MP3 lay at the northern end of Ditch 6 (Illus 11). In both instances the stratigraphic relationship between pit and ditch could not be distinguished, but SWGW was retrieved from pits MP2 and MP3. SWGW was also retrieved from MP4 and from the large linear pit MP5, which was $3.4 \mathrm{~m}$ long, $1.1 \mathrm{~m}$ wide and up to $0.72 \mathrm{~m}$ deep.

There was a distinct concentration of at least six pits between two of the furrows (Illus 3). Pits MP7MP12 were mostly sub-oval in plan, with all but one containing a single fill. Three of these pits contained sherds of SWGW, although another pit near this group, MP15, contained only sherds of 18 th- and 19th-century pottery.

Pits MP13 and MP14 lay near the southern boundary of the site (Illus 5). Pit MP13 lay adjacent to Ditch 2, in much the same way as pit MP6 lay adjacent to Ditch 3. Both pits contained sherds of SWGW, while two cereal grains from MP14 produced identical dates of cal AD 1260-1400 (Table 2; SUERC-30027 \& SUERC-30028). However,
MP13 also produced an Iron Age radiocarbon date (Table 1; SUERC-30026 - and see above).

\subsection{Structures}

In amongst the enclosures at the northern end of the site were two corn-drying kilns and some other more enigmatic structures which may be related to the agricultural activity in this area (Illus 11).

\subsubsection{Kiln 1}

Kiln 1 was the simpler of the two kilns, consisting of a pear-shaped pit which was aligned roughly ENE/ WSW. The pit measured $4.4 \mathrm{~m}$ by $2.9 \mathrm{~m}$ and was up to $0.88 \mathrm{~m}$ deep. It was filled by a series of ashy and heat-affected layers, the basal one of which may be the remnant of a clay lining in the base of the pit.

The macroplant assemblage recovered from Kiln 1 was dominated by cultivated oats, though barley, bread/club wheat and wheat/rye were also present. Sherds of SWGW were recovered from the upper fill, while a charred oat grain from a fill closer to the base of the kiln gave an earlier date range of $\mathrm{cal} \mathrm{AD}$ 990-1160 (Table 2; SUERC-30160).

\subsubsection{Kiln 2}

Kiln 2 was a more substantial structure with the more classic components of a corn-drying kiln, a stone-built drying chamber with flue. It was sub-oval in plan and was filled with deposits rich in charcoal and ash. The sides of the cut were lined with large field cobbles up to two courses in height. The base of the kiln was paved with random slabs tightly butted together; clay pointing was visible between gaps within the paving slabs. The flue enters the kiln at its south-eastern corner and appears to extend into the terminal of Ditch 8 . The flue was $1.80 \mathrm{~m}$ long, $0.70 \mathrm{~m}$ wide and $0.58 \mathrm{~m}$ deep, and its single fill contained charcoal and evidence of burning.

As with Kiln 1, the macroplant assemblage recovered from the lower fills of Kiln 2 was dominated by cultivated oats with smaller quantities of barley, bread/club wheat and wheat/rye present. An oat grain produced a radiocarbon date of cal AD 1020-1180 (Table 2; SUERC-30025). Sherds of SWGW were also retrieved from the same context as the dated cereal grain. 


\subsubsection{Timber structure?}

A cluster of post-holes lying between the eastern and western enclosures may be the remains of a timber structure (Illus 11). There are nine large post-holes which cover an area roughly $14 \mathrm{~m}$ east to west by roughly $10 \mathrm{~m}$ north to south. The post-holes are of similar diameters, between $0.50 \mathrm{~m}$ and $0.60 \mathrm{~m}$ across, but with depths varying from $0.08 \mathrm{~m}$ to $0.28 \mathrm{~m}$. Some of the post-holes contained SWGW. It is possible that they originally formed part of a sub-rectangular post-built structure.

\subsubsection{Stone platforms}

There are two other ambiguous features in amongst the Medieval activity in the northern half of the site; they are called platforms here for want of a better term. Both were overlain by deposits containing pottery sherds, mostly SWGW, but no evidence for a Medieval date came from the platforms directly and so they could be earlier in date.

Platform 1 is $7.0 \mathrm{~m}$ long by $2.2 \mathrm{~m}$ wide and was aligned north/south. It consisted of a bed of small cobbles overlain with a compacted layer of gravel. The western edge of the feature was delineated by a single course of large stones forming a kerb. Platform 1 was truncated by the remnant palaeochannel, approximately $1.6 \mathrm{~m}$ wide at this point, which was filled with water during the excavation. To the south of the palaeochannel was a small area of cobbles, which may be a continuation of Platform 1. Its location, apparently straddling what must always have been a wet, boggy area, suggests that it provided a route across this area, a trackway of sorts.

Platform 2 was a simpler feature consisting of field cobbles and angular stones which formed a crude platform a single course in height, and covering an area $5.2 \mathrm{~m}$ long by $4.3 \mathrm{~m}$. There was none of the metalling or kerbing present on Platform 1.

\section{DISCUSSION}

\subsection{Prehistoric activity}

With the exception of the possible Mesolithic pit in the north of the site, prehistoric activity at Newbridge can be defined as the fragmentary remains of Middle Bronze Age and Iron Age unenclosed settlement.
Bronze Age activity appeared to be restricted to Zone 1. Middle Bronze Age dates were recovered from Structures 1 and 2 and these suggest that Structure 2 may be a little earlier than Structure 1 . The majority of the prehistoric pottery came from Structure 1 and associated features. Although it was considered to be relatively undiagnostic, the type of pottery is not inconsistent with an MBA date. Sites with comparable ceramics include the roundhouse and associated palisades at West Acres, Newton Mearns (Toolis 2005), Lintshie Gutter, Lanarkshire (Terry 1995), and Blairhall Burn, Dumfriesshire (Strachan et al 1998).

Structures 7 and 8 provided no datable material, although Structure 8 has been indirectly dated through association with the stone hollow and the Iron Age fire-pit. Elsewhere in the Lothians these types of structures have yielded dates from the Middle Bronze Age (Lamb's Nursery, Dalkeith (Cook 2000) and Maybury Park (Moloney \& Lawson 2007)) to the Later Iron Age (Monktonhall, Inveresk (Hanson 2002), Fishers Road, Port Seton (Haselgrove \& McCullagh 2000) and Melville Nurseries (Raisen \& Rees 1995)). Structure 4 is Iron Age in date and it seems likely that Structures 5 and 6 , which are similar in morphology and size and form a cluster with Structure 4, are of similar date.

Structure 8 appears to be respected by the stone-filled hollow which forms a stone 'apron' or courtyard around its southern edge. The best parallels for this feature lie at Murton High Crags, Northumberland, where some of the stone-built roundhouses were surrounded by extensive areas of paving (Jobey \& Jobey 1987, 170, figs $6 \& 7$ ); these structures have been dated by artefacts to the early centuries AD (ibid 172). Some of the houses in the Late Iron Age village at Broxmouth have external cobbled yards associated with them, ie House 4 (Armit \& McKenzie 2013, 148-9) and House 8 (Armit \& McKenzie 2013, 171-2), but they are not as extensive as the stone-filled hollow at Newbridge. At St Germains, Tranent, East Lothian, shallow scoops lined with paving and cobbles have been interpreted as structures forming a Later Iron Age unenclosed settlement there (Alexander \& Watkins 1998, 220-2). However, these were often associated with earthcut sockets for timbers, evidence which is absent at Newbridge. Possible stone-paved settlements dating to the second century $\mathrm{AD}$ were 
also discovered at Newmains, Whitekirk, East Lothian (Stevenson 1966; Clarke 1969).

At Newbridge, activity within the hollow was confined to the double-flued fire-pit, which was Iron Age in date, and possibly P2, the large stonefilled pit under the road. The fire-pit has some structural parallels with a similar feature excavated within the vicus at Inveresk Gate, Musselburgh, East Lothian (Bishop 2004). Here, a double flue was found within a robbed-out stone 'hearth' which was also clay-lined. The excavator thought this feature was 'more sophisticated than a simple bread oven, perhaps forming the base for an enclosed "smithing hearth"' (Bishop 2004, 179; see also Sim \& Ridge $2002,57)$. The total absence of any micro-debris associated with the Newbridge fire-pit, such as iron-rich hammerscale, copper alloy droplets or other vitrified residues, makes it difficult to argue strongly for a metalworking association in this instance. As a result, the function of this feature remains open to question.

The small dimensions of Structures 4, 5 and 6 and their lack of internal features make it difficult to see them as domestic houses. Given their close proximity to the larger Structure 8 , it is possible that they are associated ancillary buildings. However, there is another possible explanation for these structures. At nearby Ratho (Smith 1995) a similar multiperiod site furnished a ring-groove $10 \mathrm{~m}$ in diameter which enclosed cremations in cordoned urns. Similar cremations within ring-groove features were found at Kinneil Mill, Linlithgow (Marriott 1968). A tight cluster of six ring-ditch features was also uncovered roughly $150 \mathrm{~m}$ away to the south of Huly Hill (Carter et al 2010,35). These ring-ditches were $7 \mathrm{~m}$ or less in diameter with no internal features, and have been tentatively identified as a barrow cemetery, possibly associated with the nearby Iron Age cart burial (ibid). If Structures 4, 5 and 6 do represent similar truncated funerary features, this increases the known extent of the ritual landscape centred around the Early Bronze Age mound on Huly Hill.

\subsection{Roman activity}

Perhaps the most significant features uncovered during the excavations are the segments of road and associated quarry pits which, for the various reasons presented below, are considered to be Roman. There is no independent evidence for a Roman date, but the Iron Age date from the fire-pit provides a terminus post quem for its construction, while the Medieval ditch boundary that cuts across it provides a terminus ante quem. Indeed, direct dating evidence for Roman roads is relatively rare. One of the few examples comes from Dere Street, where a section of the road near Pathhead was excavated revealing a substructure of brushwood and timber branches under a cobbled surface (O'Connell et al 2014). Radiocarbon dates from the timber components at this latter site were consistent with the posited latefirst-century construction for the road.

Nonetheless, the remains uncovered at Newbridge fulfil the structural criteria for Roman roads outlined by authorities such as Margery (1973) and Davies (2002) and these are considered below.

The large stones of the stone-filled hollow were used as an opportune foundation for the western segment, over which a layer of smaller stones were laid. These smaller stones could perhaps be regarded as the true formation deposits of the road, as similarsized stones formed the base of the eastern segment. Small stone formation deposits are visible in the roads excavated at the forts of Inveresk (Bishop 2004) and Cramond (Cook et al forthcoming).

The western segment exhibited a pronounced agger, with extensive patches of metalling surviving between the two kerbs. The width of metalling present is given as the main criterion in determining the traffic-carrying capacity of the road and is therefore a key indicator of both its importance and function (Davies 2002, 73). Dere Street, the main Roman supply route between northern England and eastern Scotland, is $7.7 \mathrm{~m}$ wide on average. This compares with the $7 \mathrm{~m}$ width of the segments at Newbridge. The average width of a Roman road within Britain is given as $6.51 \mathrm{~m}$ (22 pedes) (Davies 2002, 73). Wider roads in northern England and Scotland are seen as indicative of greater Roman military activity in these regions (ibid 75).

The presence of an agger and surface metalling are good indicators of Roman road construction. The agger was often formed from local materials excavated from drainage ditches running parallel to the road. At Newbridge these ditches were absent, probably because the free-draining sands and gravels of the local geology (Mitchell \& Mykura 1962, 43) made them unnecessary. P3 and P4, the two large 
quarry pits on either side of the road, may have supplied the material needed to construct the agger.

A distinctive feature of the Newbridge road is its kerbs. These are not a common feature on Roman roads but those that have them are concentrated in northern England, Wales and Scotland, probably because of the availability of suitable stone (Davies 2002, 63).

A Roman origin for the road at Newbridge is also suggested by its location. The relatively flat topography and the narrow crossing point of the River Almond at Newbridge would always have made it a natural focus for travel both east and west avoiding the foothills of the Pentlands. As it lies between the military forts at Elginhaugh and Inveresk to the east and the Antonine Wall to the west, the Newbridge road could well be a westerly continuation of Dere Street, connecting these foci.

The idea of a western road extension has long been proposed by authorities such as Keppie (1983) and Maxwell (1983), Keppie suggesting that this western extension would have headed in the direction of the eastern terminus of the Antonine Wall at Carriden. The presence of a milestone and two temporary camps along a line which would join the end of Dere Street at Inveresk with the Newbridge road (Illus 1) has always suggested that this route lay inland rather than following the coast (Maxwell 1983, 382). The Ingliston milestone was first recorded at the close of the 17 th century. It is dedicated to the Emperor Antoninus Pius and records the building or refurbishment of a road heading northwards from Newsteads in either AD 139-40 or AD 140-4 (Maxwell 1983, 383). The milestone was discovered on the east bank of the River Almond in a 'plain field, near to which severall Obelisks are to be seen', in other words near the standing stones to the east of Huly Hill (Maxwell 1983, 379). Maxwell argued that it had been found at or near its original position close to a major Roman artery of communication, citing the presence of the two probable Roman temporary camps at Gogar (Maxwell 1984), just west of Edinburgh and some $5.5 \mathrm{~km}$ east of Newbridge (Illus 1), as increasing the likelihood that Dere Street continued west of Edinburgh. He suggested that the road might cross the River Almond 'in the vicinity of Newbridge or Kirkliston' and the recent excavation has provided concrete evidence for his supposition.

\subsection{Medieval activity}

The excavations at Newbridge have revealed a large number of Medieval features spread over a considerable area, most of which are agricultural in character, such as ditches, associated pits, rig-andfurrow and corn-drying kilns. The range of Medieval agricultural features is typical of a lowland Scotland 'fermtoun', but what is missing is any evidence for the actual settlement. In each fermtoun there would have been an 'infield' of smaller fields close to the settlement, with an 'outfield' of larger fields beyond. The concentration of Medieval features at the northern end of the excavated area, where the bulk of the pottery assemblage was found, suggests that this area represents the infield and that the actual settlement probably lies to the north. There is a small knoll just to the north of the site, outside the excavated area, which would have provided a good settlement locus, with free-draining ground and south-west facing slopes.

Ditch 4 appears to define the southern extent of the infield; beyond that there is no evidence of activity until Ditch 3, which lies some $100 \mathrm{~m}$ to the south. However, the palaeochannel which weaves its way across the site from west to east may have formed the more natural boundary of the infield. It must have been an active watercourse during the Medieval period, and Platform 1 was probably a crossing point. Even today the palaeochannel retains standing water following rainfall. Its course has probably wandered over the years, obscuring and erasing the southern ends of some of the Medieval ditches and cutting through Ditch 5. To the south beyond the palaeochannel the Medieval features are more sparsely scattered and probably form part of the fermtoun's outfield of larger fields, cultivated with rig-and-furrow.

There are very few excavated Medieval rural settlements in Scotland. Since Dixon's (2003) review of Medieval rural settlement in lowland Scotland, only the sites of Eldbotle, East Lothian (Morrison et al 2008; Hindmarch \& Oram 2012) and Gogar, Edinburgh (Morrison et al 2009) have been added. At Springwood Park (Dixon 1998), Rattray (Murray \& Murray 1993) and Eldbotle, domestic buildings and associated byres were excavated, revealing a very similar history of post-built structures replaced by rectangular, stone-founded buildings, some of which 
were cruck-framed. This change to stone-founded buildings occurred in the mid-13th-14th centuries so we might anticipate that the missing settlement at Newbridge resembled those revealed at Springwood Park, Rattray and Eldbotle. At Eldbotle there were small enclosures next to the buildings but these were surrounded by stone-built walls as opposed to the ditched enclosures found at Newbridge.

Unsurprisingly, there is evidence of Medieval activity scattered along the corridor of the A8 from Newbridge towards Edinburgh, probably always a major routeway. At Norton structures associated with 12th-13th-century SWGW probably represent a fermtoun (Sneddon 2006a; Swan \& Carruthers 2006). Chemical and petrographic analyses of the pottery from Norton and Newbridge indicate that they came from different sources, suggesting that there may have been several centres in the area producing pottery (Jones \& Haggarty 2011). Medieval activity has been recorded in many of the evaluation trenches excavated in advance of the Edinburgh Tram scheme between Gogar and Edinburgh airport (Sneddon 2006b; 2007), including a kiln and a complex of Medieval ditches near Gogar Church (James 2008). Cobbled surfaces were also found here but the associated settlement remains elusive. More extensive excavations at Gogar (Morrison et al 2009) found an array of features strikingly similar to those found at Newbridge. A series of linear ditches aligned predominantly north/ south with a few east/west aligned ditches were interspersed with pits. The pits contained domestic refuse including pottery, animal bones and ash/ hearth material. As at Newbridge, these features are interpreted as 'infield' plots, or 'tofts', lying on the north-west edge of a settlement. The radiocarbon dates from Gogar suggest two phases of activity, mid-11th-mid-13th century and 13th-14th century (ibid 239). This is very similar to Newbridge, where two distinct phases of activity are suggested, one in the 11th-12th centuries, when both kilns were in use, and one in the 13th-14th centuries.

There is no evidence in the excavated area at Newbridge for activity much beyond the 14th century AD, a pattern also observed at Gogar and Springwood. This may reflect changes in agricultural practices and/or settlement patterns, brought about by a combination of deteriorating climate, major epizootic events and the effects of the Black Death during the latter half of that century (Hindmarch \& Oram 2012).

\section{SUMMARY}

Excavations at Newbridge have revealed a palimpsest of activity spanning the Middle Bronze Age to the Medieval period. Although direct dating evidence was scant, it is clear that the Newbridge site was the locus of settlement in the Middle Bronze Age and pre-Roman Iron Age. As well as the domestic structures, the settlement may also have included a semi-industrial facility represented by the fire-pit and stone-filled hollow. The small ring-groove structures on the southern boundary of the site may be part of a ritual landscape centred on Huly Hill.

The identification of a section of a Roman road is perhaps the most significant discovery of these excavations. The road lies at what is a nexus of major routeways to this very day and probably represents the link between Inveresk and Carriden. Its discovery provides solid evidence for the routeway that the Ingliston milestone and the temporary camps at Gogar have always intimated, and will facilitate the projection of this route across the landscape.

Finally, the area was farmed in the Medieval period, the associated settlement probably lying to the north of the excavated area. As Dixon $(2003,54)$ observed in his review of Medieval rural settlement, there are two important factors mitigating against finding lowland settlement, namely the efficiency of agricultural improvers in clearing old 'touns' from the post-Medieval landscape and the fact that little lowland arable land has ever been given over to pasture. Increases in industrialisation and urbanisation over the last two centuries have also led to further loss of greenfield sites and inevitably depleted the resource still further. Nonetheless, developer-funded excavations at Norton, Gogar and Newbridge are providing glimpses of the Medieval rural landscape around Edinburgh during the 11 th-14th centuries AD.

\section{ACKNOWLEDGEMENTS}

The authors would like to thank all those AOC Archaeology staff who were involved in the management and excavation of this project, 
particularly Alan Hunter Blair who supervised early phases of the excavation, and Anne Crone who made this publication happen. All on-site archaeological works and the post-excavation programme were funded by Rooster II LLP. George Haggarty, Richard Jones, Ann MacSween and Jackaline Robertson are thanked for their contributions; their full specialist reports are available in the site archive, which has been deposited with the RCAHMS.

\section{ADDENDUM: RECENT EXCAVATIONS AT} NEWBRIDGE

Nick Johnstone

\subsection{The excavated evidence}

In early 2014, as part of the phased development of the Newbridge Car Village, AOC Archaeology Group undertook an archaeological watching brief on the groundbreaking works in one of the plots,

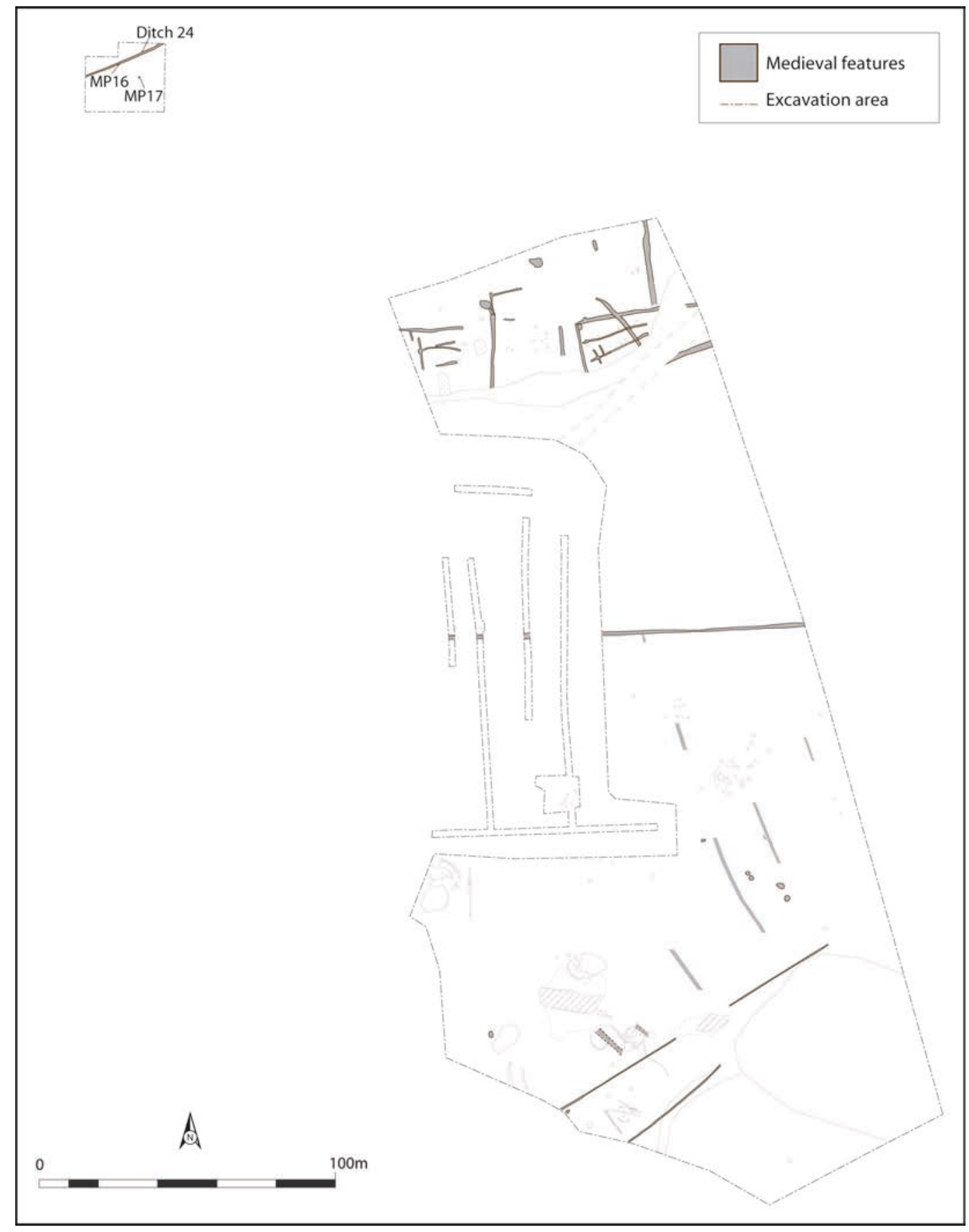

Illus 12 Plan of all excavated Medieval features. Plot 7a lies in the north-west corner of the developed area 
designated Plot 7a. Plot 7a lay approximately $120 \mathrm{~m}$ north-west of the excavations reported on above (Illus 12), and as the features uncovered during the watching brief form part of the same Medieval settlement they are reported here as an addendum to the main report. The plot covered an area of $835 \mathrm{~m}^{2}$, which was excavated mechanically in shallow spits. The only archaeological features uncovered, a ditch and two pits, lay in the northernmost corner of the plot.

Ditch 24 was orientated north-east/south-west and was exposed for a length of $28 \mathrm{~m}$, continuing beyond the excavated area in both directions. It had a steep concave profile $0.5 \mathrm{~m}$ wide by $0.3 \mathrm{~m}$ deep, and was primarily filled with a brown/grey sandy clay, although in the north-east portion it also contained a lot of rounded stones as well as a few pieces of SWGW pottery. On the southern edge of the ditch, near the transition between the change in fills, was a small round pit, MP16, $0.5 \mathrm{~m}$ in diameter and $0.2 \mathrm{~m}$ deep, which appears to just cut the edge of Ditch 24, so it is probably a later feature. A SWGW cooking pot, Vessel 1 (see below), had been deliberately set upright within the pit and packed in with grey/ brown sandy clay, within which were found other sherds of pottery (Illus 13a). A second pit, MP 17, $0.4 \mathrm{~m}$ in diameter and $0.17 \mathrm{~m}$ deep, was found to the south of Ditch 24. No artefactual or ecological remains were recovered from this feature.

The presence of SWGW pottery identifies Ditch 24 and MP16 as Medieval, and as an association of features they closely resemble the cluster of Medieval pits and ditches found to the south. It is particularly noticeable that Ditch 24 lies on the same north-east/south-west orientation as Ditches 1 and 2 on the very southern edge of the cluster, and that it is similar in size and profile to many of the other ditches. It had the same stony fill as Ditch 5, which also had a pit, MP1, cut closely into its northern edge (see Illus 11). The spread of Medieval ditches and pits in and around Zones 1 and 2 (see Illus 3) have been interpreted as the 'outfield' of an as yet undiscovered fermtoun lying to the north of Zone 3, and the features revealed in Plot 7a may reflect a similar area of outfield agriculture located to the west of this fermtoun.

While MP 16 conforms in terms of size, shape and location to the other contemporary pits of the settlement, it is unique in terms of its contents. It is the pot and its contents which are by far the most significant finds of this watching brief and they are discussed in detail below.

\subsection{The pot and its contents}

George Haggarty \& Jackaline Robertson

\subsubsection{Introduction}

The interior of Vessel 1 was excavated in spits in the laboratory and this clearly demonstrated that a large part of its base had been missing when it was interred. The sediments from the interior of the pot and from immediately beneath it were subsequently processed for the retrieval of artefacts and ecofacts (see below). Within the pot were a large number of sherds which conjoined to form about a third of another vessel (Vessel 2). Fragments of a further four vessels (Vessels 3-6) were found within the fill of the pit. Visual examination of this small assemblage tends to confirm the results of the earlier petrographic and chemical sourcing work (see above), which suggests that the SWGW pottery recovered at Newbridge derived from a number of sources. There were no signs of the igneous rocks associated with the Carboniferous volcanic rocks occurring to the north of Newbridge and with the sills closer to hand, to the north and immediate south of Newbridge.

\subsubsection{The assemblage}

Vessel 1 is a large, rounded SWGW cooking pot with a $235 \mathrm{~mm}$ base diameter. The fragment is composed of 97 sherds and crumbs, most of which have been re-conjoined (Illus 14). Most of the rim and upper body is now missing; the vessel survived in the pit to a maximum height of $c 140 \mathrm{~mm}$ (Illus 13a) but is $194 \mathrm{~mm}$ high after reconstruction (Illus 14). The vessel has also lost nearly $75 \%$ of its base, either by mishap or intentionally (Illus 13b). Its lower interior walls and remaining base are covered with splashes of a light green / pale yellow lead glaze, which suggests either that a small glazed vessel had been fired within it or that it was done intentionally. The vessel's exterior was heavily carbonised and its upper body has pronounced rilling. The lower third of its exterior had been knife trimmed and wiped horizontally. Under the microscope the fabric is a hard, very white, gritty, well-sorted paste, with 

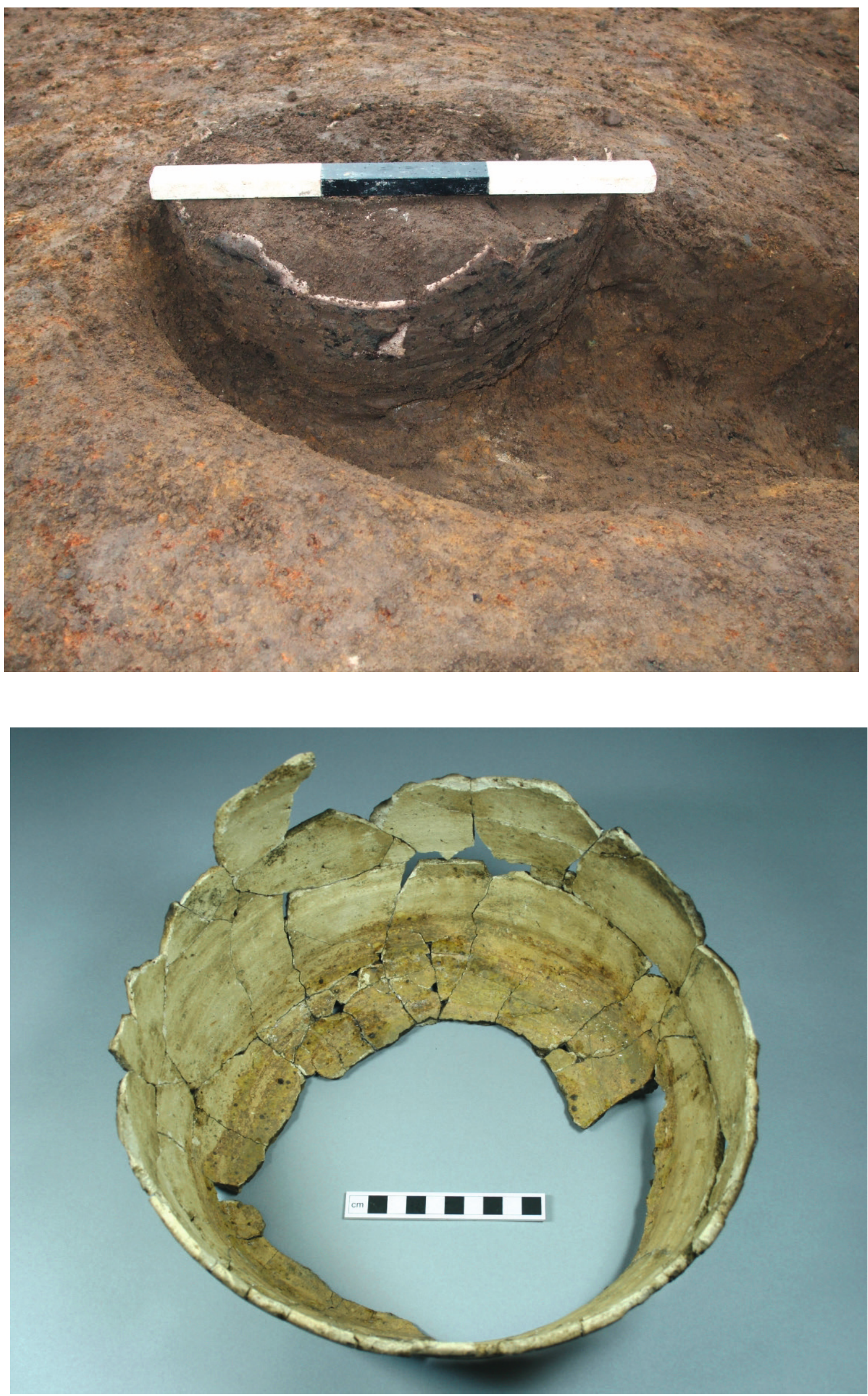

Illus 13 Vessel 1: a) in situ and b) after conservation 
abundant small quartz grains along with some larger sub-angular and sub-rounded. It does not contain the red sandstone fragments seen in Vessel 2, but has a fair amount of large, rounded, micaceous soft white sandstone grits.

Vessel 2 consists of 36 conjoining sherds, all of which were recovered during the excavation of the fill of Vessel 1. These sherds form a complete profile and about 33\% of a rounded SWGW cooking pot/ jar with an internally bevelled, square, clubbed rim and sagging base. It is $226 \mathrm{~mm}$ in height with a rim diameter of $262 \mathrm{~mm}$ and base diameter of $265 \mathrm{~mm}$ (Illus 14). The interior walls, especially towards the base, are covered with splashes of an almost yellow lead glaze, which may suggest that another, smaller, glazed vessel was fired within it. On the exterior shoulder of the vessel, $45 \mathrm{~mm}$ below its rim, is a pronounced wedge-shaped cordon. The upper body also shows pronounced rilling, while the lower third has been knife trimmed and wiped horizontally.

Under the microscope Vessel 2 is a hard, very white, gritty, well-sorted paste, with abundant small quartz grains along with some larger sub-angular and sub-rounded. There are also some burnt clasts and fairly abundant rounded red sandstone grits, along with some small other rock fragments. This is substantially different from any of the other vessels found in the pit, and from any of the sherds from earlier at Newbridge.

SWGW cooking pots/jars with pronounced wedge-shaped cordon are a form found in the Lothians and are known to have been produced at the Colstoun kiln site (Brooks 1980, 379 figs 185-93; Hall 2004, 58 fig 31). There are two
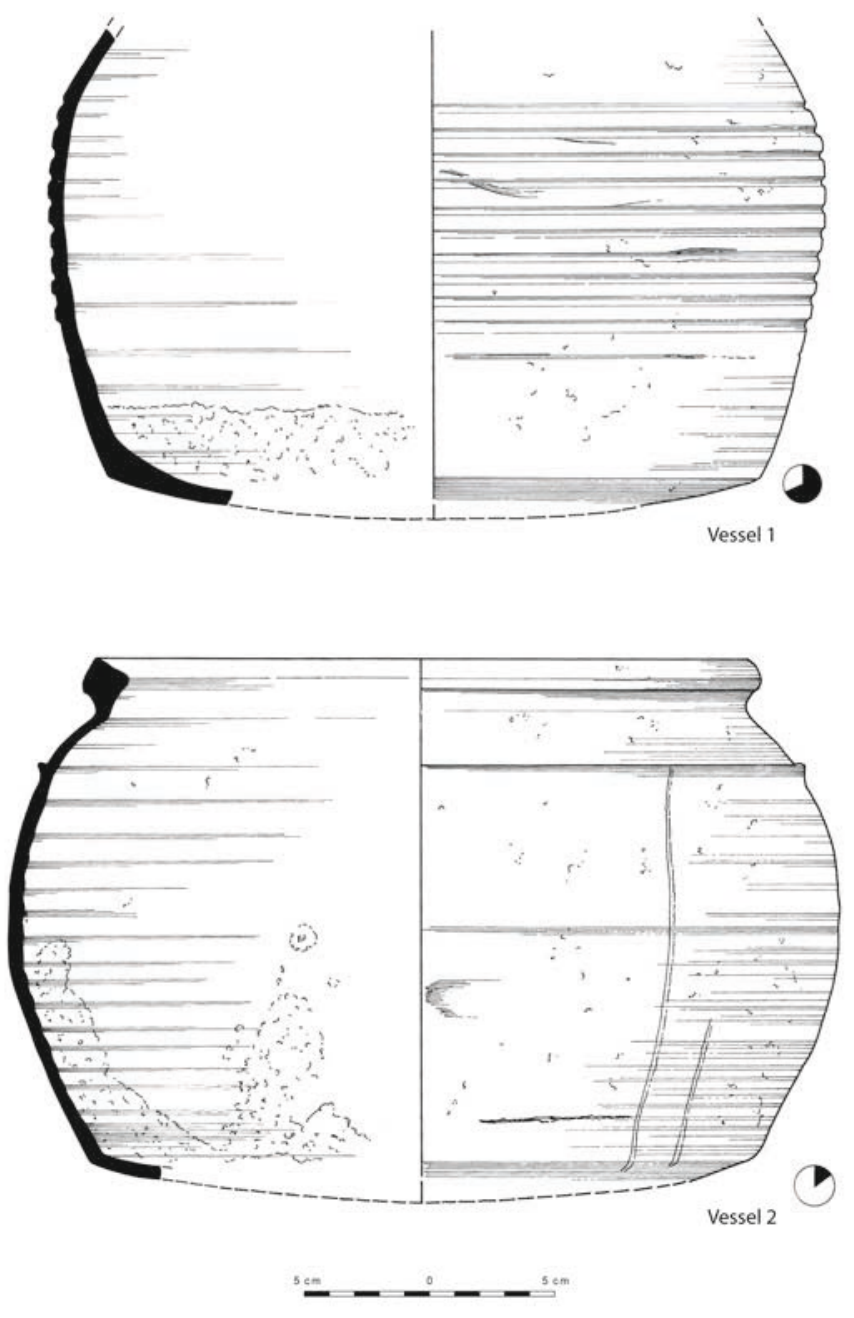

Illus 14 Vessels 1 and 2 
restored smaller vessels from an as yet unpublished excavation carried out at Ronaldson Wharf in the Port of Leith and thought to be of 13th-century date. These were both stratified above a small 12th-century straight-sided SWGW cooking pot associated with sherds of Developed Stanford ware. Almost certainly the best date for this pottery comes from a small pot discovered at Wainfleet in 1990 (Nenk 1993, 83). It contained a coin hoard consisting of 380 English Short Cross pennies and three cut Short Cross halfpennies, and has been assigned a deposition date of 1194-1204/5. This is consistent with the 12th/13th-century date ascribed to the bulk of the ceramic assemblage found during the earlier excavations at Newbridge.

Also retrieved from the fill of MP16 were four SWGW cooking pot rim sherds and four body sherds from a minimum of four different vessels (Vessels 3-6; Illus 15). One of the body sherds joins with Vessel 4. It is also possible that one of the rims may have derived from Vessel 1, as the fabrics are somewhat similar. All four rims have some traces of exterior sooting and two also have tiny specks of lead glaze. Under the microscope Vessels 3-6 seem to be quite similar, being well thrown and in a hard, very white, gritty, well-sorted paste, with abundant small

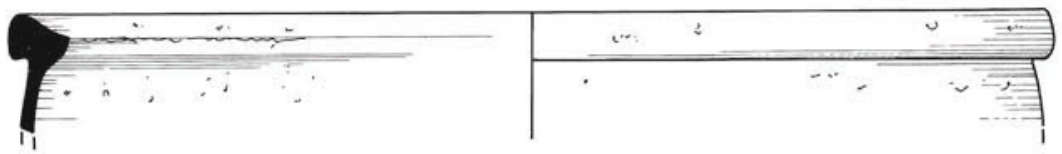

Vessel 3
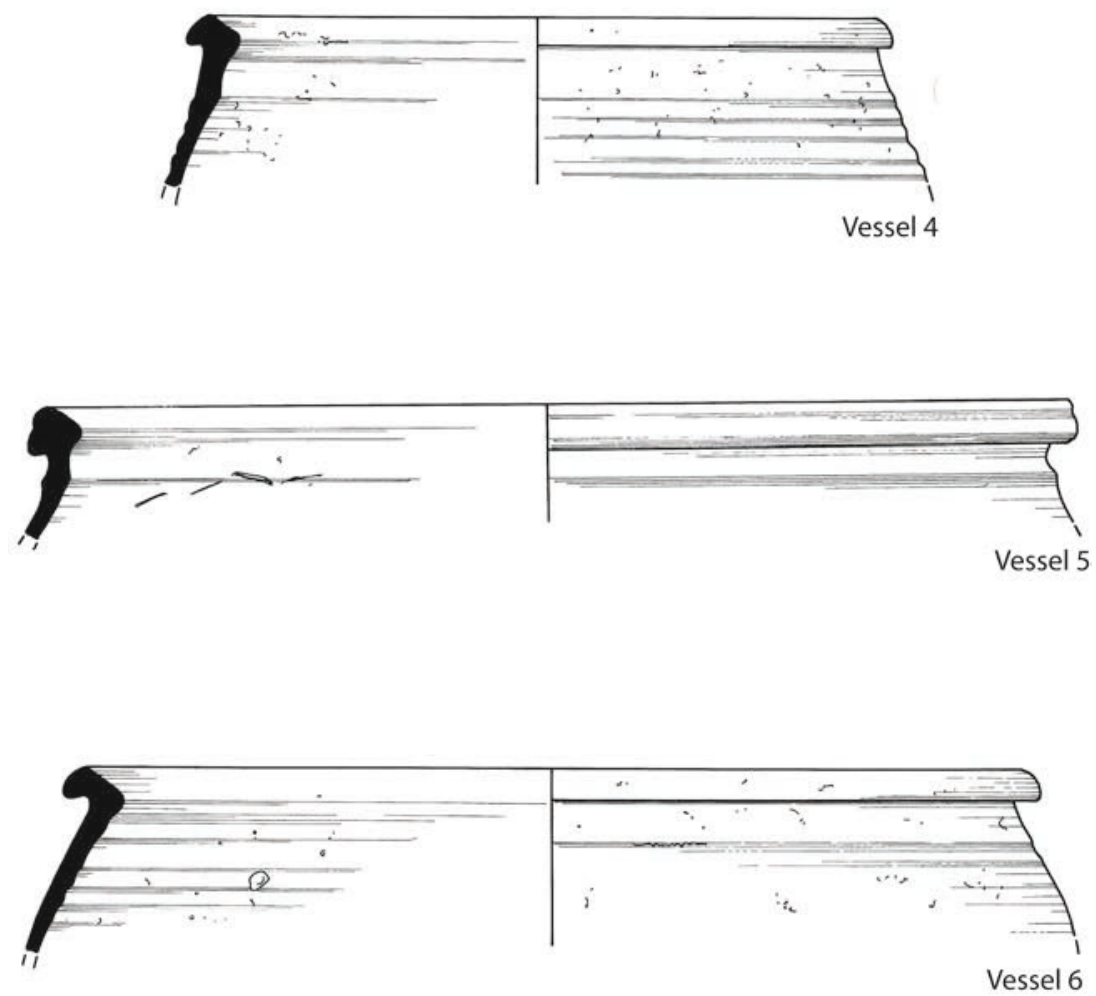

Illus 15 Vessels 3-6 
quartz grains along with some larger sub-angular and sub-rounded. There are also some burnt clasts and small, rounded, almost white, sandstone grits.

\subsubsection{The contents of the pot}

The contents of the pot were excavated in five spits, and a total of $6.5 \mathrm{~kg}$ of sediment was removed and submitted for environmental analysis. Processing produced a small macroplant assemblage and some charcoal, as well as small flecks of pottery, coal and shale. A full report including tabulated results can be found in the site archive.

A total of 18 charred macroplants were recovered from all five spits. This small plant assemblage was poorly preserved and dominated by 11 cereal caryopses. The cereal remains consisted of four bread/club wheat (Triticum aestivum-type), one wheat (Triticum sp), three oat (Avena sp) and three cereal, which could not be identified further. The preservation of the cereal remains was noticeably poor, with many appearing to have been charred at a high temperature for a prolonged period of time. These caryopses had begun to fragment and exude a tar-like substance. Only complete caryopses or those that still retained their embryo were counted as a single entity; the badly damaged cereal fragments were recorded as present but not individually counted. The remaining seven charred macroplants were so badly preserved that only a single pod segment of wild radish was recognisable.

Some $0.2 \mathrm{~g}$ of charcoal was found; the fragments were almost all smaller than $4 \mathrm{~mm}$ and were present in all five spits. Small flakes of what appeared to be a burnt organic layer were present in two spits. The flakes were relatively uniform in terms of thickness and colour and might represent food residues which had been burnt in the pot. The overall condition of this material is suggestive of a single burning event rather than the result of a continual build-up of burnt residue. A piece of fragile organic material was uncovered during the excavation of the vessel interior. Its fragile lamellar structure is similar to badly decayed marine shell such as the common oyster shell (Ostrea edulis L).

\subsubsection{Discussion}

Vessel 1 had clearly been carefully inserted in MP16 and for this reason alone we might suspect that the hole in its base had been made deliberately. Vessel 2 also appears to have been deliberately shaped; it is very roughly square and at $226 \mathrm{~mm}$ by $240 \mathrm{~mm}$ it would have covered the mouth of Vessel 1, so it may have originally acted as some form of cover. Analysis of the sediments within the pot has not helped to explain why a large Medieval cooking pot with a hole in its base had been buried, or why a ceramic lid may have covered it. The environmental finds are representative of unprocessed food and fuel residues. The presence of unground cereal caryopses, cereal chaff and common agricultural contaminants such as wild radish indicate that the cereals had not been fully processed. The assemblage is characteristic of domestic rubbish and provides no clue as to why Vessels 1 and 2 were so carefully placed within the pit.

\subsection{Acknowledgements}

The watching brief and subsequent post-excavation works were funded by Eastern Holdings (Scotland) Ltd. The ceramics were illustrated by Alan Braby, and Jamie Humble produced the site plan. 


\section{REFERENCES}

Alexander, D \& Watkins, T 1998 'St Germains, Tranent, East Lothian: The excavation of Early Bronze Age Remains and Iron Age enclosed and unenclosed settlements', Proc Soc Antiq Scot 128, 203-54.

Armit, I \& McKenzie, J 2013 An Inherited Place: Broxmouth Hillfort and the South-East Scottish Iron Age. Edinburgh: Society of Antiquaries of Scotland.

Bishop, M C 2004 Inveresk Gate: Excavations in the Roman Civil Settlement at Inveresk, East Lothian 1996-2000. Edinburgh: STAR Monograph 7.

Brooks, C M 1980 'Medieval pottery from the kiln site at Colstoun, East Lothian', Proc Soc Antiq Scot 110, 364-403.

Carter, S, Hunter, F \& Smith, A 2010 'A 5th century Iron Age chariot burial from Newbridge, Edinburgh', Proceedings of the Prehistoric Society 76, 31-74.

Clarke, D V 1969 'New Mains, Whitekirk, East Lothian', Discovery Excavation Scotland, 24.

Cook, M 2000 'Excavation of Neolithic and Bronze Age settlement features at Lamb's Nursery, Dalkeith, Midlothian', Proc Soc Antiq Scot 130, 93-113.

Cook, M, Lawson, J A \& McLaren, D forthcoming 'Excavations and interventions in and around Cramond Roman fort and annexe, 1972 to 1990', Scottish Archaeological Internet Reports.

Davies, H 2002 Roads in Roman Britain. Stroud: Tempus.

Dixon, P 1998 'A rural Medieval settlement in Roxburghshire: excavations at Springwood Park, Kelso, 1985-6', Proc Soc Antiq Scot 128, 671-751.

Dixon, P 2003 'Champagne Country: a review of Medieval settlement in Lowland Scotland', in Govan, S (ed) Medieval or Later Rural Settlement in Scotland: 10 Years On. Edinburgh: Historic Scotland, 53-64.

Hall, D W 2004 'Excavations at the pottery production centre of Colstoun, East Lothian 1939, 1971, 1977, 1999/2000', Medieval Ceramics 28, 35-74.
Hanson, W S 2002 'Amongst the field systems I: Monktonhall', in Bishop, M (ed) Roman Inveresk: Past, Present and Future. Duns: The Armatura Press, 52-61.

Haselgrove, C \& McCullagh R 2000 An Iron Age Coastal Community in East Lothian: The Excavation of two Later Prehistoric Enclosure Complexes at Fishers Road, Port Seton, 1994-5. Edinburgh: STAR Monograph Series 6.

Hindmarch, E \& Oram, R 2012 'Eldbotle: the archaeology and environmental history of a medieval rural settlement in East Lothian', Proc Soc Antiq Scot 142, 245-99.

James, H 2008 'Edinburgh Tram Scheme: Gogar Church, City of Edinburgh (Edinburgh parish), excavation and preservation in situ', Discovery Excavation Scotland 9, 72.

Jobey, I \& Jobey, G 1987 'Prehistoric, RomanoBritish and later remains at Murton High Crags, Northumberland', Archaeologia Aeliana 15, 151-98.

Jones, R \& Haggarty, G 2011 A Report and Catalogue on Medieval and Later White Gritty Pottery from Kirkliston Road, Newbridge, Edinburgh. Unpublished report for AOC Archaeology Group.

Keppie, L J F 1983 'Roman inscriptions from Scotland: some additions and corrections', Proc Soc Antiq Scot 113, 398.

MacSween, A 2010 The Prehistoric Pottery from Newbridge. Unpublished report for AOC Archaeology Group.

Margery, I D 1973 Roman Roads in Britain. London: John Baker.

Marriott, J W 1968 'A Bronze Age burial site at Kinneil Mill, Stirlingshire', Proc Soc Antiq Scot 100, 86-99.

Maxwell, G S 1983 'Two inscribed Roman stones and architectural fragments from Scotland', Proc Soc Antiq Scot 113, 379-90.

Maxwell, G 1984 'Gogar Roman temporary camp', Discovery Excavation Scotland, 16.

Mitchell, G H \& Mykura, W 1962 The Geology of the Neighbourhood of Edinburgh. Edinburgh: HMSO.

Moloney, C \& Lawson, J A 2007 'Excavations at Maybury Park, Edinburgh (1990-2)', Scottish Archaeological Internet Reports, 23. 
Morrison, J, Oram, R \& Oliver, F 2008 'Ancient Eldbotle unearthed: archaeological and historical evidence for a long-lost early medieval village', Transactions of the East Lothian Antiquarian \& Field Naturalists' Society, 27, 21-45.

Morrison, J, Oram, R \& Ross, A 2009 'Gogar: archaeological and historical evidence for a lost medieval parish near Edinburgh', Proc Soc Antiq Scot, 139, 229-55.

Murray, H K \& Murray, J C 1993 'Excavations at Rattray, Aberdeenshire: a Scottish deserted burgh', Medieval Archaeology, 37, 109-218.

Nenk, B 1993 'A developed Stamford Ware coinhoard pot from Wainfleet, Lincolnshire', Medieval Ceramics, 17, 83.

O'Connell, C, White, R \& Cressey, M 2014 'Excavation across the Dere Street Roman Road at Dun Law, Scottish Borders', Scottish Archaeological Internet Report 57.

Raisen, P \& Rees, T 1995 'Excavations of three cropmark sites at Melville Nurseries, Dalkeith', Glasgow Archaeological Journal, 19, 31-50.

Robertson, J 2011 Newbridge: The Macroplant Assemblage. Unpublished report for AOC Archaeology Group.

Sim, D \& Ridge, I 2002 Iron for the Eagles. Stroud: Tempus.

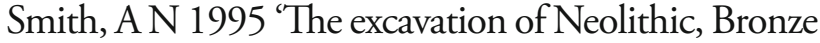
Age and Early Historic features near Ratho, Edinburgh', Proc Soc Antiq Scot, 125, 69-138.

Sneddon, D 2006a 'Norton House Hotel', Discovery Excavation Scotland, 7, 77.

Sneddon, D 2006b 'Edinburgh Tram Scheme: Gogar, City of Edinburgh (Kirkliston parish), evaluation', Discovery Excavation Scotland, 7, 76.

Sneddon, D 2007 'Edinburgh Tram Scheme: City of Edinburgh (Edinburgh and Edinburgh and Kirkliston parishes), evaluation', Discovery Excavation Scotland, 8, 85.

Stevenson, R B K 1966 'New Mains, Whitekirk, East Lothian', Discovery Excavation Scotland, 25.

Strachan, R, Ralston, I \& Finlayson, B 1998 'Neolithic and later prehistoric structures, and early medieval metal-working at Blairhall Burn, Misfield, Dumfriesshire', Proc Soc Antiq Scot, 128, 70-5.

Swan, D \& Carruthers, M 2006 'Norton House Hotel', Discovery Excavation Scotland, 7, 77.

Terry, J 1995 'Excavation at Lintshie Gutter unenclosed platform settlement, Crawford, Lanarkshire, 1991', Proc Soc Antiq Scot, 125, 369-427.

Toolis, R 2005 'Bronze Age pastoral practices in the Clyde Valley: excavations at West Acres, Newton Mearns', Proc Soc Antiq Scot, 135, 471-504. 